FAUSTO JOSÉ MARTINS SEABRA

\title{
A ATUAÇÃO DO JUIZ NA EFETIVAÇÃO DA TUTELA COLETIVA
}

MESTRADO EM DIREITO

UNIVERSIDADE DE SÃO PAULO

SÃO PAULO - 2008 
SUMÁRIO

\section{A RELEVÂNCIA E O CONTEXTO DAS AÇÕES COLETIVAS}

1.1. Aspectos históricos, econômicos, sociais, políticos e jurídicos.

1.2. Mauro Cappelletti e a doutrina brasileira.

1.3. Evolução legislativa no Brasil.

1.4. Os interesses e direitos difusos e coletivos.

1.4.1. Conceitos.

1.4.2. Vacilações da prática forense.

1.5. As ações coletivas e a ordem constitucional.

1.6. Lineamentos da experiência norte-americana.

1.7. O intercâmbio dos sistemas processuais.

1.8. As injunctions e a tutela inibitoria italiana.

\section{OS PROVIMENTOS JUDICIAIS BRASILEIROS}

2.1. Natureza e alcance.

2.2. A polêmica da classificação.

2.3. Os provimentos segundo a situação de direito material.

2.4. Alguns provimentos do direito comparado.

3. DAS MEDIDAS PARA A EFETIVAÇÃO DOS PROVIMENTOS

3.1. Hipóteses de incidência.

3.2. Discricionariedade ou criatividade judicial.

3.3. Limites.

3.4. Medidas sub-rogatórias.

3.5. Medidas de coerção e de sanção.

3.5.1. Contempt of court.

3.5.2. Astreintes.

3.5.3. Outras medidas.

4. CONCLUSÕES 
Ao Professor Kazuo Watanabe, mais do que um jurista,

um ser humano sábio e paciente, exemplo a ser seguido.

À família Seabra, em especial a Maria Thereza e Carlos Heitor, pelas lições que não se ensinam em nenhuma escola.

Aos amigos Fábio Pacheco e Adriana Spinelli do Amaral pelo companheirismo e apoio em todos os momentos. 


\section{Introdução}

O projeto inicial da dissertação de mestrado apresentado ao Professor Kazuo Watanabe na entrevista realizada em dezembro de 2004, depois de superadas duas difíceis etapas do processo seletivo para o ingresso no curso de pós-graduação do Largo de São Francisco, versava sobre "o juiz e as ações coletivas". Perguntado sobre o interesse nessas ações, respondi-lhe que os motivos eram preponderantemente práticos, já que na Comarca em que atuava era freqüente o ajuizamento de ações coletivas pelo Ministério Público, ao passo que no exercício das atividades de magistrado e de professor universitário, decidira voltar à condição de aluno e me aperfeiçoar sob a orientação dos sucessores da Escola Processual de São Paulo, abrigo de estudantes de todo o Brasil, fazendo minhas as palavras de consagrado processualista ${ }^{1}$.

Porém, "a variação da perspectiva de conhecimento traz, como é cediço, resultados surpreendentes" 2 , os quais foram surgindo nos semestres letivos de 2005 com a leitura e o estudo dos textos obrigatórios e facultativos sugeridos pelos docentes, e da freqüência às inesquecíveis aulas da disciplina "Processos Coletivos", regida com maestria por Ada Pellegrini Grinover e Kazuo Watanabe. O contato com ambos, o convívio com Carlos Alberto de Salles, Paulo Henrique dos Santos Lucon e José Marcelo Menezes Vigliar - docentes responsáveis pela coordenação dos seminários bem como os debates, indagações e críticas oriundas das outras visões e carreiras jurídicas dos colegas da pós-graduação descortinaram novos caminhos para a dissertação.

Concluí que o projeto original envolvia muito mais os aspectos sociais, filosóficos, econômicos, políticos e deontológicos da magistratura, do que as questões exclusivamente processuais e, assim, exige um amadurecimento que só o tempo e o estudo contínuo permitirão. Não obstante, o tema inicial persistiu e como se tratava de um trabalho de processo civil, e não de sociologia jurídica ou de filosofia do direito, concentrou-se nos provimentos jurisdicionais, já que constituem a exteriorização da

\footnotetext{
1 "Mas o juiz moderno, que se preocupa com o aperfeiçoamento, que volta ao convívio universitário nos cursos de doutorado e especialização, que acompanha o desenvolvimento científico através de leituras atualizadas, vai percebendo que uma nova imagem se forma no campo do direito processual" (Cândido Rangel Dinamarco. Fundamentos do processo civil moderno, p. 254).

${ }^{2}$ Kazuo Watanabe. Da cognição no processo civil, p. 17.
} 
atividade do juiz, independentemente de suas opções políticas, ideológicas, culturais e mesmo religiosas.

Portanto, não é escopo deste texto debater temas como o ativismo judiciário ou a politização dos juízes, o emprego das demandas coletivas para a implantação de políticas públicas e outros tantos relacionados aos processos coletivos, mas tratados sob óticas e princípios alheios ao direito processual.

Entre outros objetivos, ao tratar da tutela jurisdicional dos interesses do consumidor e criar um sistema de ações coletivas, pretendia o legislador estimular os agentes estatais a uma nova mentalidade no tratamento dos conflitos de massa e criar técnicas diferenciadas para a proteção dos direitos coletivos.

A Lei $\mathrm{n}^{\circ} 8.078 / 90$ vige há mais de uma década, todavia ainda se nota a falta de assimilação dessa nova mentalidade por segmentos do Poder Judiciário, presos a dogmas inerentes aos conflitos individuais, além de tímidos ou, no extremo oposto, arbitrários na aplicação dessas novas técnicas para a efetivação da tutela coletiva, instrumento de inegável magnitude, repercussão e vantagens para a pacificação social.

Impõe-se a eliminação dessas vacilações e a superação de antagonismos infrutíferos, sobretudo num momento em que a atuação jurisdicional é severamente criticada pelo anacronismo e pela ineficiência das tradicionais fórmulas decisórias das lides. Os anseios pela real aptidão da prestação jurisdicional na solução dos conflitos exigem uma leitura mais consentânea de princípios e institutos processuais. Com a ruptura de alguns cânones seculares do processo civil individual, as técnicas conferidas às demandas coletivas propiciam a extração de resultados úteis para a efetividade das decisões judiciais.

É inegável a exigência de um papel mais ativo ao juiz moderno, em especial no momento em que lhe incumbe transformar em realidade a regra que formulou ao decidir o caso concreto. A antiga premissa de que o juiz esgota a sua atividade ao proferir a sentença não espelha a freqüente necessidade de o magistrado emitir outros e novos comandos para satisfazer e assegurar o direito reconhecido.

O desenvolvimento do trabalho se inicia com o histórico e a relevância das ações coletivas, as atuais controvérsias sobre a identificação dessas demandas, bem como alguns aspectos e considerações críticas sobre as ações coletivas norteamericanas, paradigma universal. Estabelecidas algumas bases para sustentar o intercâmbio entre os ordenamentos processuais, sempre com o cuidado de preservas as 
peculiaridades de cada sistema jurídico, passa-se ao estudo dos provimentos judiciais e, finalmente, das medidas para a sua efetivação.

As principais questões analisadas dizem respeito às características e aos limites dos provimentos judiciais nas obrigações de fazer e não fazer, bem como das medidas para assegurar o efetivo cumprimento dessas decisões judiciais. Conforme será visto no decorrer do trabalho, os provimentos para a entrega de coisa ou para o pagamento de quantia em dinheiro, de ocorrência excepcional nas ações coletivas, não foram tratados de modo aprofundado, já que o seu regime e disciplina não suscitam tantas dificuldades práticas na hipótese de descumprimento. Em regra, a resistência à entrega de coisa se dissipa com a expedição de mandado judicial de reintegração de posse ou de busca e apreensão, enquanto que o inadimplemento da obrigação de pagar determinada soma se resolve com a expropriação de bens do devedor.

\section{A relevância e o contexto das ações coletivas}

\subsection{Aspectos históricos, econômicos, sociais, políticos e jurídicos.}

Fugiria aos propósitos desta exposição traçar um exaustivo histórico das ações coletivas no direito nacional e no direito estrangeiro, à medida que a mera reprodução ou síntese de textos, ainda que elaborados por fontes seguras e consagradas, não teria nenhuma utilidade.

Expressiva doutrina considera que as ações coletivas não são um fenômeno contemporâneo ${ }^{3}$ e cita a ação popular do Direito Romano como o antigo e precursor instrumento utilizado pelos cidadãos para a tutela de interesses de caráter não privado, como os relacionados à desobstrução de caminhos e à aplicação de penalidades pecuniárias a quem atirasse objetos sobre as vias públicas.

Incerta a verdadeira origem das ações coletivas, não faltam referências à Inglaterra medieval, em que grupos demandaram ou foram demandados em

\footnotetext{
${ }^{3}$ V. Márcio Flávio Mafra Leal. Ações coletivas: história, teoria e prática; Celso Antonio Fiorillo, Marcelo Abelha Rodrigues e Rosa Maria de Andrade Nery. Direito processual ambiental brasileiro; Elival da Silva Ramos. A ação popular como instrumento de participação política; Aluisio Gonçalves de Castro Mendes. Ações coletivas no direito comparado e nacional; Gregório Assagra de Almeida. Direito processual coletivo brasileiro, passim.
} 
controvérsias relativas a interesses metaindividuais desde o século XII ${ }^{4}$ e, a partir do século XVII, por intermédio do instituto do bill of peace ${ }^{5}$, as ações coletivas passaram a depender da verificação da presença de interesses comuns de um número elevado de pessoas, as quais se vinculavam aos efeitos da coisa julgada.

Mais importante do que identificar as origens remotas ou próximas das ações coletivas é compreendê-las na conjuntura de uma economia globalizada e dos seus reflexos jurídicos, sociais e políticos.

A incessante industrialização do período pós-guerras, a explosão demográfica, o êxodo rural, a competitividade dos mercados e dos postos de trabalho, bem como a progressiva escassez de recursos naturais, são alguns dos fatores determinantes das sensíveis alterações produzidas nas relações sociais e, em conseqüência, no próprio Direito, cuja primordial função de dar resposta aos conflitos foi e é seriamente afetada pelo constante estado de tensão e de desequilíbrio entre os grupos e pela ineficácia de suas normas formais e fechadas, alheias à dinâmica e à instabilidade sociais.

A pressão dos setores produtivos para que lhes sejam outorgadas regras específicas e, assim, obtenham tratamento jurídico especial com a remoção dos obstáculos para a consecução de seus interesses é prontamente atendida pelos agentes estatais e resulta numa inflação normativa que corrói a idéia de um sistema legal orgânico e coerente ${ }^{6}$ e dificulta a compreensão dos direitos e deveres de cada um.

Impulsionada pela idéia de que a eficiência econômica é a meta a ser alcançada para melhorar a qualidade de vida dos indivíduos, a antiga noção de Estado como o ente unificador das diversas estruturas políticas e depositário dos anseios sociais é substituída pela atividade de criador, fomentador e supervisor de políticas públicas ${ }^{7}$.

\footnotetext{
${ }^{4}$ Há divergências entre os estudiosos, pois alguns consideram que o primeiro caso de ação coletiva teria ocorrido em 1179 na França, quando aldeões de uma vila postularam o fim da condição de servos (v. Márcio Flávio Mafra Leal. Ações coletivas: história, teoria e prática, p. 21).

${ }^{5}$ Espécie de autorização concedida ao indivíduo para que litigasse na condição de autor e representante do grupo, fazendo com que a demanda fosse tratada de modo uniforme e impedindo a multiplicação de processos.

6 A observação é de José Eduardo Faria: “Ao aumentar de modo cada vez mais desordenado e desarticulado o número de matérias, atividades e comportamentos regulados por textos legais, essa desenfreada produção legislativa culmina, assim, na ruptura da organicidade, da unidade lógico-formal e da racionalidade sistêmica do ordenamento jurídico e, por conseqüência, na perda da própria capacidade de predeterminação das decisões concretas por meio do direito positivo" ( $O$ direito na economia globalizada, p. 117).

7 As quais não se reduzem às questões econômicas: "Essas políticas, não obstante, não se reduzem à categoria das políticas econômicas, mas antes, de modo mais amplo, englobam todo o conjunto de atuações estatais no campo social (políticas sociais). A expressão políticas públicas, assim, designa todas as atuações do Estado, cobrindo todas as formas de intervenção do Poder Público na vida social" (Eros Roberto Grau. A ordem econômica na Constituição de 1988, p. 20).
} 
Tradicionais institutos jurídicos como o matrimônio, o contrato e a propriedade privada, não mais correspondem aos modelos legais traçados sob contextos ultrapassados. Famílias são constituídas à margem do casamento solene e formal, milhares de contratos são padronizados e a livre fruição de bens é limitada para a preservação de novos valores (meio-ambiente, urbanismo, função social da propriedade etc).

Inerentes à natureza humana, os conflitos de interesses assumem moldura coletiva. A antiga disputa de Caio e Tício por um pedaço de pão foi sucedida pelos litígios entre grupos, categorias e classes sobre bens jurídicos de caráter universal, não apropriáveis com exclusividade e que afetam indistintamente as pessoas ${ }^{8}$.

Diante desse quadro e da inaptidão dos instrumentos tradicionais de solução de controvérsias de natureza individual para dirimir os conflitos de massa ${ }^{9}$ é que se acentua a importância da tutela coletiva, independentemente da opção ideológica ou filosófica do intérprete ${ }^{10}$, que não pode fechar os olhos à realidade: muitas das carências e das aspirações dos seres humanos, conquanto possam ser identificadas de forma individual, assumiram uma feição coletiva.

\subsection{Mauro Cappelletti e a doutrina brasileira.}

A preocupação dos processualistas brasileiros com a tutela coletiva surge no final da década de 70 e se intensifica a partir dos anos 80 do século $\mathrm{XX}$, sendo nitidamente estimulada e influenciada pelo pensamento de Mauro Cappelletti ${ }^{11}$.

\footnotetext{
8 "Mas é somente em épocas recentes que novos corpos intermediários começam a surgir e a proliferar: novos grupos, novas categorias, novas classes de indivíduos, conscientes de sua comunhão de interesses, de suas necessidades e de sua fraqueza individual, unem-se contra as tiranias da nossa época, que não é mais exclusivamente a tirania dos governantes: a opressão das maiorias, os interesses dos grandes grupos econômicos, a indiferença dos poluidores, a inércia, a incompetência ou a corrupção dos burocratas" (Ada Pellegrini Grinover. A problemática dos interesses difusos, "in" A tutela dos interesses difusos, p. 33).

${ }^{9}$ A expressão "massa" não é empregada como antônimo de "elite", mas sim no sentido de um grande número de indivíduos tratados de maneira coletiva e mais ou menos uniforme.

${ }^{10}$ Ao tratar do bem individual e do bem coletivo, aderindo à corrente do personalismo, afirma Miguel Reale que "a satisfação daquilo que interessa à sociedade, tomada como um todo, nem sempre representa a satisfação de cada indivíduo, que possui algo de irredutível ao social" (Filosofia do direito, p. 278). Descarta, portanto, o individualismo, pelo qual a satisfação individual trará o bem coletivo, bem como o transpersonalismo, o qual refuta a coexistência harmônica entre o bem individual e o bem do todo, que é condição essencial para a felicidade individual. A corrente personalista "não estabelece a priori uma tese no sentido do predomínio do indivíduo ou do predomínio do todo, mas se coloca numa atitude aderente à realidade histórica, para saber, em cada circunstância, na concreção e fisionomia de cada caso, o que deve ser posto e resolvido em harmonia com a ordem social e o bem de cada indivíduo" (id., ibid., p. 279).

${ }^{11}$ Não se esqueceram outros importantes autores italianos como Vicenzo Vigoriti, Vittorio Denti e Andrea Proto Pisani, que também ofereceram importantes estudos sobre a tutela coletiva.
} 
Discípulo de Piero Calamandrei e falecido em 2004, pouco antes de completar 77 anos, sempre mostrou interesse pelos aspectos políticos do processo e entre as suas obras destacam-se as três ondas renovatórias do direito processual, sintetizadas no acesso à Justiça pelas pessoas carentes de recursos materiais, na reformulação e aperfeiçoamento dos procedimentos, e na tutela dos direitos coletivos ${ }^{12}$.

À luz da realidade social de seu tempo - muito mais complexa e articulada do que as formações sociais primitivas - sustentava a superação da clássica e insuficiente divisão entre direitos públicos e privados. A produção e o consumo em massa alteraram a natureza dos conflitos, que deixaram de ser exclusivamente individuais e atingiram grupos e classes, mostrando o profundo abismo entre o público e o privado. Sem diferenciar os termos difusos ${ }^{13}$ e coletivos, empregados pela generalidade da doutrina italiana como sinônimos, lembrava da proteção do meio ambiente, da defesa dos consumidores e dos pequenos e médios acionistas perante grupos econômicos, isto é, dos interesses e direitos que não são públicos nem privados ${ }^{14}$.

Atento ao direito comparado e em especial às ações coletivas norte-americanas expunha as dificuldades operacionais da tutela coletiva, as quais se iniciam com a legitimação ativa, passam pelas garantias processuais dos membros ausentes do grupo ou da classe e deságuam nos efeitos e na extensão da coisa julgada, assim como na necessidade de criação de mecanismos judiciais para garantir a efetividade das decisões.

Jurista à frente de seu tempo, Mauro Cappelletti deixou valioso legado aos processualistas de todo o mundo. Não teve receio de questionar dogmas aceitos incondicionalmente. Na incessante busca pelo efetivo acesso à Justiça, produziu trabalhos históricos que ainda hoje têm o frescor do novo.

Num escrito pioneiro, destinado a volume de estudos em homenagem a Enrico Tullio Liebman, preparado em Florença e publicado em 1977 no Brasil, José Carlos Barbosa Moreira discorreu sobre o emprego da ação popular brasileira para a tutela dos

\footnotetext{
${ }^{12}$ Este trabalho emprega as expressões coletivo, coletiva, coletivos e coletivas em sentido amplo, isto é, abrangendo também os interesses e direitos difusos. Quando tratarmos de interesses e direitos coletivos na definição estrita do CDC haverá a necessária identificação.

${ }^{13}$ Interesse difuso seria um misterioso personagem para Massimo Villone. (Cf. La collocazione istituzionale dell'interesse diffuso, p. 73).

${ }^{14}$ Assim escreveu: "Nossa época, já tivemos oportunidade de ver, traz prepotentemente ao palco novos interesses 'difusos', novos direitos e deveres que, sem serem públicos no senso tradicional da palavra, são, no entanto, coletivos: desses ninguém é 'titular', ao mesmo tempo que todos os membros de um dado grupo, classe ou categoria, deles são titulares. A quem pertence o ar que respiro? O antigo ideal da iniciativa processual monopolística centralizada nas mãos de um único sujeito, a quem o direito subjetivo 'pertence', se revela impotente diante de direitos que pertencem, ao mesmo tempo, a todos e a ninguém" (Formações sociais e interesses coletivos diante da justiça civil, p. 135).
} 
direitos difusos ${ }^{15}$. Lembrava que a Constituição Federal de 1934 já previa a proteção desses interesses e que a Lei $n^{\circ} 4.717 / 65$ ampliou o espectro desta ação ou remédio constitucional de invalidação de ato que cause não apenas prejuízo pecuniário, mas também "quando lese bens imateriais ou refratários a uma avaliação em termos de moeda, como são, em regra, aqueles que constituem objeto dos chamados 'interesses difusos" "16. Lamentava o autor a ausência, naquela época, de um instrumento específico na Lei da Ação Popular com a capacidade para tutelar de modo eficiente os interesses coletivos que, nem sempre, são assegurados ou restaurados satisfatoriamente com a condenação ao ressarcimento de perdas e danos. Defendia, assim, o manejo das medidas cautelares com a aplicação supletiva dos artigos 798 e 799 do Código de Processo Civil.

No ano seguinte, Waldemar Mariz de Oliveira Júnior e Ada Pellegrini Grinover publicam trabalhos sobre a tutela coletiva. O primeiro consolidou palestras e conferências proferidas desde 1976 sob o título "Tutela jurisdicional dos interesses coletivos", enquanto o segundo texto, na forma de tese apresentada à VII Conferência Nacional da OAB, chamava-se "A tutela jurisdicional dos interesses difusos". Os escritos foram apresentados quase simultaneamente e sem que a autora citada conhecesse o primeiro trabalho.

No final de 1982 e sob a coordenação de José Alberto Weiss de Andrade e Ada Pellegini Grinover, realizou-se na Faculdade de Direito do Largo de São Francisco uma série de oito palestras sobre a tutela dos interesses coletivos ${ }^{17}$. No painel de encerramento ${ }^{18}$ formou-se um grupo ${ }^{19}$ destinado a elaborar um anteprojeto de lei para a proteção de interesses difusos, o qual foi aprovado em vários institutos e congressos. $\mathrm{O}$

\footnotetext{
${ }^{15}$ Sem o objetivo de "caracterizar dogmaticamente" os interesses difusos, o autor lembrava da vacilante terminologia empregada aos interesses "superindividuais", ora denominados difusos, ora denominados coletivos pela doutrina italiana.

${ }^{16}$ A ação popular do direito brasileiro como instrumento de tutela jurisdicional dos chamados interesses difusos', p. 115. Vários conceitos e ponderações expostos nesse histórico trabalho foram incorporados no plano legislativo. É o caso, por exemplo, da relação-base de que participam todos os membros do grupo e que hoje caracterizam os interesses coletivos stricto sensu. Outros importantes estudos desenvolvidos pelo autor sobre a tutela coletiva desde 1980 foram publicados especialmente na $3^{\text {a }}$ série dos conhecidos Temas de direito processual.

${ }^{17}$ Foram conferencistas: Waldemar Mariz de Oliveira Jr., Ada Pellegrini Grinover, Paulo Affonso Leme Machado, René Ariel Dotti, Kazuo Watanabe, José Carlos Barbosa Moreira, Waldírio Bulgarelli e Fábio Nusdeo.

${ }_{18}$ Do qual participaram os coordenadores e Antonio Magalhães Gomes Filho, Cândido Rangel Dinamarco, Jackson Gouveia de Barros, Renato Guimarães Júnior, Tércio Sampaio Ferraz Jr. e Waldemar Mariz de Oliveira Jr.

${ }^{19}$ Formado por Ada Pellegrini Grinover, Cândido Rangel Dinamarco, Kazuo Watanabe e Waldemar Mariz de Oliveira Jr.
} 
seminário resultou numa obra, à qual foram acrescidos jurisprudência e trabalhos forenses ${ }^{20}$.

Além do caráter inovador, impressiona nesses textos a determinação de seus autores em buscar e encontrar no incipiente ordenamento jurídico então em vigor os fundamentos da tutela coletiva, propiciando uma interpretação ampla da legitimidade extraordinária do art. $6^{\circ}$ do Código de Processo Civil.

Com a vigência da Lei da Ação Civil Pública em julho de 1985 e, mais de cinco anos depois, com o Código de Defesa do Consumidor ${ }^{21}$, a tutela coletiva ganhou merecido destaque e é tema constante em livros, seminários, congressos e disciplinas dos cursos de graduação e pós-graduação brasileiros.

\subsection{Evolução legislativa no Brasil.}

Antes da Lei $\mathrm{n}^{\mathrm{o}} 7.347 / 85$ era um esforço descomunal encontrar em nosso ordenamento jurídico instrumentos de defesa de direitos coletivos além da ação popular $\left(\text { Lei } \mathrm{n}^{\mathrm{o}} 4.717 / 65\right)^{22}$. Destinada à invalidação de atos ilegais e lesivos ao patrimônio público e conferindo legitimidade ativa ao cidadão, convivia tal ação de defesa de direitos difusos com outras escassas modalidades de tutela coletiva como a do art. 513 da Consolidação das Leis do Trabalho, o revogado Estatuto da Advocacia (Lei $\mathrm{n}^{\mathrm{o}}$ 4.215/63) e a Lei de Política Nacional do Meio Ambiente (Lei n ${ }^{\circ}$ 6.938/81) ${ }^{23}$.

Justamente com o propósito inicial de disciplinar a "ação de responsabilidade civil e criminal por danos causados ao meio ambiente", prevista pelo art. $14, \S 1^{\circ}$, da citada lei ${ }^{24}$, surgiu a Lei da Ação Civil Pública ${ }^{25}$, cujo objeto e legitimados foram

\footnotetext{
${ }^{20}$ A tutela dos interesses difusos.

${ }^{21}$ Respectivamente, Leis no $7.347 / 85$ e 8.078/90.

22 Waldemar Mariz de Oliveira Jr. cita doze normas, entre leis, regulamentos e decretos que possibilitavam de alguma maneira essa tutela coletiva. Cf. Tutela jurisdicional dos interesses coletivo, "in" A tutela dos interesses difusos, p. 13/15.

${ }^{23}$ No primeiro caso, o sindicato é legitimado para representar os interesses gerais da respectiva categoria ou profissão liberal; no segundo, à OAB é outorgada a qualidade de representante dos interesses gerais da classe e; no terceiro, o Ministério Público é legitimado à ação reparatória de danos causados ao meio ambiente.

${ }^{24} \mathrm{E}$ a partir do anteprojeto elaborado pela comissão de juristas formada depois do mencionado seminário de 1982.

${ }^{25}$ Ao que parece, a primeira referência à "ação civil pública" foi feita pela Lei Complementar $n^{\circ} 40 / 81$, que tratava das normas gerais para a organização do Ministério Público dos Estados. A qualificação "pública" é equívoca e resulta em interpretações distorcidas acerca dos legitimados ativos.
} 
ampliados, mas suprimiu-se o controle da representatividade adequada pelo juiz, tornando-a ope legis ${ }^{26}$.

Em 1988 foi constitucionalizada a tutela coletiva ${ }^{27}$. A Magna Carta eliminou da garantia de acesso à Justiça a expressão direito individual constante dos textos anteriores e contemplou com isso os direitos coletivos, mencionados no art. 129, inciso III e $\S 1^{\text {o } 28}$.

Com o Código de Defesa do Consumidor, especialmente em razão de seu art. 110, que autorizou o uso da ação civil pública para a defesa de "qualquer outro interesse difuso ou coletivo", consolidou-se o microssistema ${ }^{29}$ das ações coletivas, permitindo-se ainda a tutela dos interesses individuais homogêneos e dos coletivos stricto sensu.

Outras leis vigentes tratam da tutela coletiva, tais como o Estatuto da Criança e do Adolescente, a Lei de Improbidade Administrativa, a Lei dos Portadores de Deficiência Física e o Estatuto do Idoso.

\subsection{Os interesses e direitos difusos e coletivos.}

Ontologicamente distintos, os termos interesse e direito foram conjugados pelo Código de Defesa do Consumidor a fim de permitir a ampla tutela coletiva e eliminar possíveis questionamentos teóricos que impediriam o pleno acesso ao Poder Judiciário. Não apenas os direitos, mas também os interesses ${ }^{30}$, arrolados nos incisos I,

\footnotetext{
${ }^{26}$ No anteprojeto original a representatividade adequada da associação autora era aferida a critério do juiz e era revelada por dados como: "estar constituída há seis meses, nos termos da lei civil; incluir, entre suas finalidades institucionais, a proteção ao meio ambiente ou a valores artísticos, estéticos, históricos, turísticos ou paisagísticos".

${ }^{27}$ Para Gregório Assagra de Almeida, a partir da CF de 1988 é possível falar em direito processual coletivo comum brasileiro como um novo ramo do direito processual (Direito processual coletivo brasileiro, p. 266).

${ }^{28}$ Tratam da legitimação do Ministério Público e terceiros para a promoção de ações destinadas à "proteção do patrimônio público e social, do meio ambiente e de outros interesses difusos e coletivos".

${ }^{29}$ Para Nelson Nery Jr., "há, por assim dizer, uma perfeita interação entre os sistemas do CDC e da LACP, que se completam e podem ser aplicados indistintamente às ações que versem sobre direitos ou interesses difusos, coletivos e individuais, observado o princípio da especialidade das ações sobre relações de consumo, às quais se aplica o Título III do CDC, e só subsidiariamente a LACP. Esse interagir recíproco de ambos os sistemas (CDC e LACP) tornou-se possível em razão da adequada e perfeita compatibilidade que existe entre eles por força do CDC e, principalmente, de suas disposições finais, alterando e acrescentando artigos ao texto da Lei ${ }^{\circ}$ 7.347/85" (Código brasileiro de defesa do consumidor comentado pelos autores do anteprojeto, p. 995).

30 "Interesse não significa um juízo, mas uma posição do homem, ou mais exatamente: a posição favorável à satisfação de uma necessidade" (Francesco Carnelutti. Sistema de direito processual civil, vol. I, p. 55). Segundo Elio Fazzalari, o termo direito atualmente se identifica com a noção de ordenamento jurídico, isto é, um modelo fracionário "constituído pelo conjunto de normas jurídicas e de condutas a elas referentes cujo encontro (ou desencontro no caso da repressão do ilícito), tende a realizar a ordem de uma dada sociedade" (Instituições de direito processual, p. 52).
} 
II e III do art. 81 da Lei $n^{0}$ 8.078/90 são protegidos por "todas as espécies de ações capazes de propiciar sua adequada e efetiva tutela" (art. 83, caput).

Sem a correta assimilação dos conceitos criados pelo legislador, corre-se o risco de a atuação do juiz (e seus provimentos) se revelar inoperante ou acarretar a prematura rejeição de direitos.

\subsubsection{Conceitos.}

Interesses ou direitos difusos são os transindividuais ${ }^{31}$, de natureza indivisível, e cujos titulares são pessoas indeterminadas e ligadas por circunstâncias de fato. Exemplo clássico é o do direito ao meio ambiente sadio, a partir do qual podem ser extraídas características que os diferenciam dos demais. A indeterminação do titular é absoluta e ninguém pode ser apropriar dessa modalidade de direito de modo individual, dada a sua indivisibilidade.

Rodolfo de Camargo Mancuso anota outras duas peculiaridades dos interesses difusos: a intensa conflituosidade e a duração efêmera, contingencial. A latência do conflito é explicada pelo fato de que se originam de simples acontecimentos não necessariamente ligados por um vínculo jurídico claro e preciso, de sorte que "não há um parâmetro jurídico que permita um julgamento axiológico preliminar sobre a posição 'certa' e a 'errada",32.

Basta pensar na recente polêmica que envolve a transposição do Rio São Francisco. Os defensores da obra sustentam que ela levará água a 12 milhões de pessoas, revitalizará o rio, aumentará a capacidade de gerenciar os recursos hídricos nacionais e colocará fim à chamada indústria da seca, enquanto que os opositores argumentam que haverá favorecimento a empreiteiras, o projeto não se assenta em estudos aprofundados, o gasto será maior do que o previsto e o benefício inferior ao prometido.

A mutação dos interesses difusos no tempo e no espaço é outra característica que decorre de sua própria natureza. A mudança se dá com absoluta informalidade jurídica, bastando a alteração nas circunstâncias fáticas. Em conseqüência, "não demonstram eles aptidão para serem completamente tutelados em sede legislativa que, a

\footnotetext{
${ }^{31}$ Hugo Nigro Mazzilli considera correto o neologismo transindividual, formado com prefixo e radical de origem latina, ao contrário de metaindividual, também largamente usado pela doutrina e jurisprudência, mas composto com prefixo grego e radical latino. A defesa dos interesses difusos em juízo, p. 45.

${ }^{32}$ Interesses difusos: conceito e legitimação para agir, p. 72.
} 
princípio, seria a indicada, visto que esses interesses implicam em verdadeiras escolhas politicas ${ }^{33}$.

Esse dinamismo factual exige aguçada percepção e sensibilidade do magistrado ao emitir provimentos. De nada adiantará, por exemplo, a ordem para coibir determinada atividade nociva ao meio ambiente se cessada voluntária e definitivamente a prática anterior, mas se há necessidade de implantar de imediato algumas medidas compensatórias para minorar as conseqüências do dano já causado.

Interesses ou direitos coletivos também são transindividuais e de natureza indivisível. Contudo, há relativa determinação de seus titulares, quer por meio da relação jurídica base que os une, quer por meio do vínculo jurídico diante da parte contrária. São os casos dos membros de uma associação de classe ou dos contribuintes do mesmo tributo, tais como a $\mathrm{OAB}$ ao defender o chamado quinto constitucional nos tribunais e os sujeitos passivos do IPTU.

Mas essa possibilidade de determinação dos titulares não significa que constituam a soma ou o ajuntamento de interesses individuais, muito menos que consubstanciam os interesses pessoais do grupo, isto é, da própria pessoa jurídica. Nos interesses coletivos há uma síntese de interesses individuais, que amalgamados “desvanecem os interesses individuais originários, surgindo uma nova realidade: a dos interesses (verdadeiramente) coletivos" ${ }^{\text {34 }}$.

A organização desses interesses ou direitos não é absoluta, já que só existirá para aqueles pertencentes a grupo, categoria ou classe de pessoas ligadas entre si por uma relação jurídica base. Não haverá necessidade dessa organização e, portanto, não estará descartada a tutela coletiva, se houver o vínculo jurídico apenas com a parte contrária, assinalando-se ainda que em todos os casos a relação jurídica base não nasce com a própria lesão ou ameaça de lesão aos direitos do grupo, mas é preexistente ${ }^{35}$.

Finalmente, os interesses ou direitos individuais homogêneos são divisíveis e seus titulares perfeitamente identificáveis. A defesa de tais direitos se dá, em regra, individualmente, mas a Lei $\mathrm{n}^{\circ} 8.078 / 90$ propiciou a sua tutela coletiva em juízo por meio de uma única demanda, que guarda algumas semelhanças com as class actions norte-americanas, e de iniciativa do substituto processual desses indivíduos ${ }^{36}$.

\footnotetext{
${ }^{33}$ Id., ibid., p. 76.

${ }^{34}$ Rodolfo de Camargo Mancuso. Interesses difusos: conceito e legitimação para agir, p. 39.

${ }^{35}$ Kazuo Watanabe. Código brasileiro de defesa do consumidor..., p. 803/805.

${ }^{36}$ A tutela coletiva de direitos individuais ainda é foco de intensas perplexidades e questionamentos, que se iniciam justamente na legitimidade ativa para essas demandas. Ressalta José Marcelo Menezes Vigliar
} 


\subsubsection{Vacilações da prática forense.}

Não obstante o elevado estágio atingido pela doutrina no que toca à solidificação e uniformização dos conceitos acima vistos, a realidade dos juízos e tribunais está muito distante desse quadro teórico. A pulverização de demandas coletivas para a tutela de idênticos interesses e que amiúde resultam em julgamentos confrontantes, a veiculação de ações individuais cujo objeto só poderia ser tutelado coletivamente e o ajuizamento de ações civis públicas para a salvaguarda de direitos não coletivos são algumas das demonstrações da enorme distância entre o ideal do legislador e o real do dia a dia do Poder Judiciário.

Tornaram-se comuns as demandas pseudocoletivas e, no sentido oposto, a atomização ${ }^{37}$ de ações individuais ou coletivas para a tutela de direitos transindividuais, consoante observam Luiz Paulo da Silva Araújo Filho e Kazuo Watanabe, respectivamente. Nas primeiras, "conquanto tenha sido proposta a ação por um único legitimado extraordinário, na verdade estão sendo pleiteados, específica e concretamente, os direitos individuais de inúmeros substituídos, caracterizando-se uma pluralidade de pretensões que, em tudo e por tudo, é equiparável à do litisconsórcio multitudinário"38. Nas ações pseudoindividuais, o fenômeno é inverso, já que "são individuais apenas no sentido de que são propostas por indivíduos, mas a pretensão é de alcance coletivo, pois beneficia a totalidade das pessoas que se encontram na mesma situação, e não somente o autor da ação. Em semelhante situação, seria suficiente uma só demanda, seja individual ou coletiva" 39 .

\footnotetext{
que o problema não é tutela coletiva para a defesa de direitos individuais, mas sim "naquele que se apresentará para a defesa do interesse em juízo. A representatividade - sem trocadilhos lamentáveis tornará o autor da demanda tanto mais legitimado quanto mais adequado representante se mostrar. Ora, é claro que o caso concreto revelará essa representação, esse compromisso com o gênero do evento tutelado no caso concreto" (Interesses individuais homogêneos e seus aspectos polêmicos, p. 57).

${ }^{37}$ Átomo em grego significa inseparável. Demócrito denominava de átomos os pedaços de um objeto que, de tão pequenos, seria impossível separá-los. Molécula, por sua vez, é a união dos átomos com a formação de partículas maiores. A intenção do legislador era tratar molecularmente os conflitos de interesses coletivos "para com isso conferir peso político maior às demandas coletivas, solucionar mais adequadamente os conflitos coletivos, evitar decisões conflitantes e aliviar a sobrecarga do Poder Judiciário atulhado de demandas fragmentárias" (Kazuo Watanabe. Demandas coletivas e os problemas emergentes da práxis forense, p. 191).

${ }^{38}$ Ações coletivas: a tutela jurisdicional dos direitos..., p. 200.

${ }^{39}$ Relação entre demanda coletiva e demandas individuais, p. 29.
} 
Tais distorções podem ser atribuídas a equívocos freqüentes na aferição dos elementos e das condições das ações coletivas pelo juiz.

Partes, pedido e causa de pedir são os elementos identificadores das ações tanto individuais como coletivas. Nestas, a legitimidade ativa é ampla (incisos do art. 82 do Código de Defesa do Consumidor) e, a partir do isolamento preciso da causa de pedir e do pedido, determinar-se-á com segurança o alcance da demanda e a presença de eventual conexão ou litispendência.

Constituindo-se a causa de pedir no fato ou no conjunto de fatos "a que o autor atribui a produção do efeito jurídico por ele visado" nela é possível distinguir um aspecto ativo (fato constitutivo) e um passivo (fato lesivo) ${ }^{40}$. Assim, se da narrativa constante da petição inicial se depreende a existência e a violação de interesses ou direitos de natureza transindividual e caráter indivisível e, se o pedido formulado é coletivo, bastará "uma só demanda coletiva para a proteção de todas as pessoas titulares desses interesses ou direitos" $" 41$.

\subsection{As ações coletivas e a ordem constitucional.}

Embora pareça inócua e sem significado prático a busca de fundamentos para afirmar a existência de um direito processual constitucional como ramo autônomo da ciência do Direito ${ }^{42}$, o estudioso contemporâneo, atento aos escopos jurídicos, sociais e políticos do processo em sua ótica instrumentalista, de modo invencível é impelido a compreendê-lo e dele extrair os melhores resultados à luz dos valores inseridos na ordem constitucional.

Afinal, a Constituição é a matriz, o ponto de partida, o tronco comum dos ramos do Direito $^{43}$ e no qual seus frutos devem encontrar a necessária coerência

\footnotetext{
40 José Carlos Barbosa Moreira. O novo processo civil brasileiro, p. 17.

${ }^{41}$ Kazuo Watanabe. Demandas coletivas e os problemas emergentes..., p. 190. Para Ricardo de Barros Leonel, na exposição da causa petendi das ações coletivas é necessário ir além da narrativa do conflito jurídico e descrever os fundamentos axiológicos do pedido, "a justificar a pretensão do autor, demonstrando a maior relevância, benefício comum, ou correção sob o prisma do interesse coletivo da opção almejada, em cotejo com aquela impugnada" (A causa petendi nas ações coletivas, p. 161).

${ }_{22}$ Para Cintra-Pellegrini-Dinamarco, trata-se "de uma colocação científica, de um ponto-de-vista metodológico e sistemático, do qual se pode examinar o processo em suas relações com a Constituição" (Teoria geral do processo, p. 79).

${ }^{43}$ Segundo Liebman, "ciò è vero in senso formale e sostanziale: perché il diritto costituzionale regola la formazione delle leggi ed è da esso che tutte le norme derivano la loro giuridicità; ma anche perché il diritto costituzionale regola nei suoi aspetti fondamentali la posizione delle persone singole, dei gruppi
} 
sistemática $^{44}$, sobretudo nos princípios e garantias fundamentais que informam as relações entre os indivíduos, os agrupamentos sociais e o Estado.

À medida que consiste num método de exame do sistema processual à luz dos preceitos contidos na Constituição Federal, o direito processual constitucional abrange a tutela constitucional do processo e a jurisdição constitucional das liberdades, estabelecendo relações entre a Constituição e o processo numa via de dupla mão de direção: de um lado, a Constituição atrela o sistema processual a princípios e garantias cujo objetivo final é o de permitir o acesso à justiça; de outro, o processo serve de instrumento de efetivação e atuação dos princípios constitucionais, podendo até influir nas mutações da ordem jurídica ${ }^{45}$.

Para Eduardo J. Couture o acesso à justiça deve ser outorgado com a máxima generosidade. Convém que a lei processual se inspire nos valores constitucionais, num intercâmbio imprescindível entre a Constituição e o processo, já que o exame das instituições processuais culminará sempre num momento em que terão a característica de direitos fundamentais, como o direito de ação e de petição aos órgãos públicos para a remoção de entraves ao exercício da cidadania ${ }^{46}$.

Se as assertivas e as conclusões anteriores são válidas para os processos destinados à solução de conflitos individuais, muito mais significado adquirem quando nos deparamos com controvérsias que extrapolam os interesses ou direitos suscetíveis de ser condensados na clássica equação da pretensão resistida de um sujeito, inerente à concepção de que a atividade jurisdicional existe para a solução de conflitos entre indivíduos isoladamente considerados.

sociali e dei poteri pubblici nella società giuridicamente constituta, cosicché gli altri rami del diritto, destinati a regolare l'attività degli uomini nelle più svariate circostanze della vita, altro non sono che specificazioni e svolgimenti delle norme della costituzione" (Problemi del processo civile, p. 149/150).

${ }^{44}$ Conferindo méritos à estática e à dinâmica jurídica de Kelsen, Norberto Bobbio recomenda o estudo do Direito a partir de métodos indutivos: da norma ao contexto de normas (ordenamento jurídico), considerando-se não apenas a "árvore", mas toda a "floresta" (Teoria do ordenamento jurídico, p. 20).

${ }^{45}$ Cf. Cândido Rangel Dinamarco, A instrumentalidade do processo, p. 30/43. Anna Cândida da Cunha Ferraz, por sua vez, sustenta que a interpretação judicial capaz de provocar mutações constitucionais pode ser evolutiva (ou adaptadora), adequadora, criativa e analógica e, que em todas elas "exsurge, nítido, o papel de mutação constitucional da interpretação judicial que, sem alterar a letra ou o espírito da norma constitucional, lhe dá novo significado ou alcance para, aplicando-a, torná-la o que se pretende que ela seja: um documento vivo e efetivamente cumprido" (Processos informais de mudança da Constituição, p. 130).

${ }^{46}$ Nas palavras do autor: "basta pensar en el examen de las instituciones esenciales del derecho procesal civil, se llega siempre a un instante en que éstas adquieren el rango de derechos cívicos o fundamentales. Derecho cívico es la acción, si se considera que ella en último término, es el acto de petición a la autoridad, indispensable para que condene al demandado, para que declare la existencia de un derecho o para que quite un embarazo al libre ejercicio de una situación jurídica" (Estudios de derecho procesal civil, p. 22/23). 
O inegável aparecimento de interesses e direitos que não são públicos nem privados impôs uma nova leitura do direito de ação, especialmente no confronto com o poder estatal. $\mathrm{Na}$ lição de Kazuo Watanabe, a ação vai além da simples tutela de um direito subjetivo e torna-se "uma forma de participação pública através do Judiciário, como instrumento de racionalização do poder". 47

Tal fenômeno pode ser atribuído, conforme a pertinente nota de Carlos Alberto de Salles, à superação do Estado liberal, responsável pela garantia da autonomia dos cidadãos, por um Estado social, "implementador de políticas públicas" e que "deve ordenar a alocação de recursos e a realização de ações, de forma a serem alcançados os vários objetivos sociais, expressos através dos vários processos decisórios da sociedade e integrados a textos legais". 48

E é justamente nesse contexto que surge a proteção judicial dos interesses e direitos coletivos, a exigir mecanismos próprios de tutela, haja vista a insuficiência dos modelos tradicionais para a sua afirmação e efetivação ${ }^{49}$.

Imprescindível, pois, absorver uma nova concepção da atividade jurisdicional voltada ao trato das ações coletivas ${ }^{50}$.

\subsection{Lineamentos da experiência norte-americana.}

A diferenciada atividade jurisdicional nas demandas coletivas é evidente nos Estados Unidos da América, nação habituada aos litígios metaindividuais e onde grandes corporações e agrupamentos sociais protagonizam verdadeiros duelos que nem sempre se submetem às decisões políticas de seus juízes e júris populares, haja vista o expressivo número de transações nessas demandas.

\footnotetext{
${ }^{47}$ Tutela jurisdicional dos interesses difusos: a legitimação para agir, p. 97.

${ }^{48}$ Políticas públicas e a legitimidade para defesa de interesses difusos e coletivos, p. 39.

${ }^{49}$ Defendendo a existência de um direito processual coletivo como ramo próprio do direito processual, Gregório Assagra de Almeida sustenta que isso é necessário "para a verdadeira tutela dos direitos ou interesses coletivos" (Direito processual coletivo brasileiro, p. 29). Pela primeira vez, e depois de 20 edições de sua consagrada obra, Cintra, Grinover e Dinamarco afrimam que "sendo caracterizado por princípios e institutos próprios, o direito processual coletivo pode ser separado, como disciplina processual autônoma, do direito processual individual" (Teoria geral do processo, $21^{\mathrm{a}}$ ed., p. 133). Nos anos 70, Mauro Cappelletti e Bryant Garth já assinalavam a insuficiência do esquema tradicional do processo civil para a tutela coletiva: "The traditional conception os civil procedure left no room for the private, non-governamental protection of diffuse interests. Litigation was seen as merely a two-party affair, aimed at settling a controversy between the parties about their own individual rights" (Acess to justice, vol. I, p. 35).

${ }^{50}$ Tratando da tutela coletiva nos estatutos modernos, Cândido R. Dinamarco destaca a denominada molecularização das demandas, na feliz observação de Kazuo Watanabe, fenômeno resultante do direito de massa, que impõe novos rumos ao processo civil ( $A$ reforma do CPC, p. 28/30).
} 
Mas ao dar significado aos valores públicos e solucionar controvérsias, o juiz norte-americano realiza a adjudicação ${ }^{51}$, atividade que no final dos anos 50 e início dos anos 60 do século passado foi denominada de reforma estrutural em virtude de seu caráter constitucional e do confronto entre o Poder Judiciário e as burocracias estatais (escolas, hospícios, hospitais, prisões e outras).

O marco dessa reforma estrutural é apontado por Owen Fiss no caso "Brown vs Board Education”, de 1954, que envolvia a segregação racial numa escola. No escopo de tornar a instituição de ensino unitária e, com isso, cumprir a decisão que consagrara o ensino multirracial naquele país, houve o esforço constante e a necessidade ininterrupta de promover drásticas reformas organizacionais nas estruturas existentes com a inserção de novos procedimentos seletivos de alunos e professores, de modificação de currículos e de redirecionamento de verbas, entre outras tantas atividades com as quais os juízes não tinham nenhuma intimidade ou preparo para bem desempenhá-las.

Apesar de a Suprema Corte, sob a presidência de Earl Warren não ter um projeto administrativo minucioso, colocou em prática a decisão, delegando poderes a juízes federais que, por sua vez, adaptaram as formas tradicionais do procedimento para atender a contingências que iam surgindo na efetivação do decidido.

Porém, no final dos anos 70, alterou-se a composição da Suprema Corte que, dividida internamente, chegou a criticar de forma vigorosa a reforma estrutural.

A maior parte das críticas a essa reforma é fundada no fato de que os juízes têm muito poder. Num precedente dos anos $30^{52}$, definiu-se que o papel das Cortes decorria da falha administrativa, isto é, o Judiciário se submeteria ao Legislativo, a não ser que os processos da legislatura fossem inadequados (p.ex., restrição ao direito de voto ou discriminação de uma minoria). A justificativa era a de que o Legislativo (assim como os outros órgãos do governo) e, ao contrário do Judiciário, estaria mais atrelado às políticas majoritárias.

A teoria da falha administrativa é incoerente, visto que parte da presunção de que é exata a atividade legislativa, sem considerar que uma minoria determinada e isolada pode ser prejudicada. Na realidade, o processo legislativo nem sempre é conexo aos valores constitucionais, conquanto esteja em regra atrelado às preferências da população. Já “a função do juiz não é falar pela minoria ou aumentar a sua

\footnotetext{
${ }^{51}$ Adjudication, que não corresponde à adjudicação brasileira, mas sim ao processo social de escolha das soluções possíveis para dirimir o litígio.

52 "United States vs Carolene Products Co".
} 
expressividade, mas dotar os valores constitucionais de significado, o que é feito por meio do trabalho com o texto constitucional, história e ideais sociais. Ele procura o que é verdadeiro, correto ou justo, não se tornando um participante nos interesses das políticas de grupo". 53

$\mathrm{Na}$ busca do verdadeiro significado dos valores constitucionais, que não depende necessariamente da falha de outra instituição (legislativa ou executiva), o juiz deve ser acima de tudo objetivo a fim de não expressar suas crenças ou preferências pessoais. Dois aspectos the outorgam tal objetividade: a obrigação de participar do diálogo processual (contraditório), que implica em resolver as demandas que lhe são submetidas e fundamentar suas decisões, e a independência, a qual se expressa na ausência de ligações ou vínculos com os envolvidos.

A teoria da reforma estrutural exige que o juiz possa se pronunciar e o faça com autoridade, dependendo não de seus atributos pessoais ou de sua mensagem, mas "da capacidade de estar distanciado e separado das partes e do corpo político e, ao mesmo tempo, dar total atenção à demanda proposta, sendo predisposto a dar respostas que transcendam preferências e sejam suficientes para fundamentar um julgamento considerado "constitucional"" 54.

O modo estrutural é criticado porque estaria distanciado de uma forma ideal, de um modelo para comparação com as ações judiciais. O modelo tradicional da tríade (a balança e o conflito entre dois indivíduos), além de individualista, difere da transformação que se pretende operar com a reforma estrutural.

Mas essa transformação apresenta as seguintes peculiaridades: a) quanto ao foco do processo judicial: não é direcionada para as transações ou os incidentes privados, mas para as condições da vida social e para o papel que as organizações de grande porte desempenham na determinação dessas condições; b) quanto à estrutura das partes: na reforma estrutural há desintegração da unidade implícita no conceito de parte, incluindo grupos sociais e advogados institucionais, cabendo à Corte examinar se os interesses estão devidamente representados, sem embargo da possibilidade de múltiplos representantes nos pólos ativo e passivo e das diferentes medidas judiciais; c) quanto à postura do juiz: na reforma estrutural seu papel é mais ativo, agindo de ofício quando necessário quer convidando organizações ou órgãos públicos para participar do processo (amicus curiae) quer nomeando representantes para a prática de atos

\footnotetext{
${ }^{53}$ Um novo processo civil, p. 36.

${ }^{54}$ Owen Fiss. Um novo processo civil, p. 46.
} 
específicos (special master); d) quanto à fase de execução: no processo estrutural não é esporádica como nos outros processos, visto que implica na eliminação de uma condição que ameaça os valores constitucionais, exigindo muitas vezes acompanhamento e reorganização de uma instituição por longo prazo.

A transformação ainda significa que o papel das Cortes não é de mera solução de controvérsias, mas sim o de dar significado aos valores constitucionais. $\mathrm{O}$ entendimento de que elas existem para solucionar um conflito na qualidade de terceiro não capta a sua verdadeira lógica social, que á e do soberano que envia seus oficiais para todo o território sob o seu controle, a fim de dizer o direito e verificar se ele está sendo cumprido.

A adjudicação difere da arbitragem, a qual deve ser reservada para as controvérsias de caráter privado e que não ameacem ou tragam conseqüências para um valor público. Na arbitragem, o órgão responsável pela solução é privado e é remunerado pelas partes, enquanto na adjudicação, o juiz é funcionário público, "autorizado pelos órgãos políticos a criar e implementar normas sociais amplas e, talvez, até mesmo, a reestruturar instituições". 55

Uma vez que a reforma estrutural é fiel à função da adjudicação de dar significado aos valores públicos, o processo estrutural deve adaptar-se à realidade social em transformação, na qual a vida social é dominada pelas organizações burocráticas. $\mathrm{O}$ poder das Cortes é limitado pela vontade e habilidade do juiz, enquanto que a presença de muitos interesses e pessoas, não prejudica o "diálogo" consistente na oitiva dos litigantes e no pronunciamento judicial.

Para reconstruir a burocracia estatal o juiz é impelido a abandonar sua posição de independência para ingressar no mundo das políticas. $\mathrm{O}$ dilema em que se vê o juiz ao determinar uma medida que não apenas declare o que é certo ou errado, mas que também seja exeqüível e suficiente decorre de alguns formalismos; por exemplo, a concepção de que o remédio judicial deve se adequar à violação do direito (princípio determinante), ignorando-se que o objeto da medida estrutural não é a eliminação da violação, mas sim o afastamento da ameaça imposta aos valores constitucionais. As medidas judiciais, portanto, são de caráter prospectivo e não retrospectivo.

A violação não é a única fonte da medida judicial. Em muitas ocasiões será necessário optar por medidas subsidiárias ou adicionais, fundamentais para efetivar a

\footnotetext{
${ }^{55}$ Owen Fiss. Um novo processo civil, p. 68.
} 
execução, mediante discricionariedade eqüitativa, de grande relevância em cada caso concreto. Ademais, a medida judicial sempre estará aberta a revisões, principalmente se não se revelar eficaz ou for assaz onerosa.

Não se pode negar, por outro lado, que o instrumentalismo da medida é suscetível de falhas, não apenas por ser conduzido por uma Corte, fato que suscitará questionamentos sobre a sua legitimidade na condução de políticas públicas, como também porque a ameaça aos valores constitucionais poderá persistir. Todavia, as medidas constituem a própria realização do direito (são mais específicas, concretas e coercitivas do que a mera declaração do direito) e são hábeis para levar em consideração as diferenças entre as comunidades, conduzindo a remédios judiciais diferentes. " $\mathrm{O}$ êxito do processo de implementação depende de várias outras forças menos formais, menos identificáveis e, talvez, até mesmo menos fáceis de serem alcançadas" 56.

No que toca às ações coletivas para a tutela dos direitos dos consumidores, sustenta Charles Keckler a sua natureza efetivamente econômica: "são como uma espécie de negócio para as pessoas que estão engajadas nessa área”. Assimétricas, dispõem-se tais ações a compensar as desigualdades provocadas pelas atitudes predatórias de um grande produtor contra a massa de consumidores.

Todavia, a realidade norte-americana mostra que os elevados ônus impostos ao réu dessas demandas, cuja vitória num determinado estado não lhe garante o mesmo resultado nos demais, estimula a celebração de acordos globais para "comprar a paz de espírito" em todo o território nacional e baratear os elevados custos na defesa de inúmeras ações espalhadas pelos diversos condados, evitando ainda decisões desfavoráveis de juízes eleitos em campanhas eleitorais financiadas com o dinheiro obtido por advogados especializados em ações coletivas.

Conquanto as estatísticas exibam a sociedade americana de modo diverso do que comumente se acredita (propensa a litígios), esse grupo de advogados especializados (2.000) transformou o sistema de ações coletivas "do local onde se consertava o que estava errado em uma oportunidade de investimento e, até que isso seja controlado, continuarão a existir problemas significativos em relação às ações coletivas nos Estados Unidos" ${ }^{\circ 7}$.

\subsection{O intercâmbio dos sistemas processuais.}

\footnotetext{
${ }^{56}$ Owen Fiss. Um novo processo civil, p. 100.

${ }^{57}$ Ações coletivas em relações de consumo, p. 99.
} 
Numa época em que as decisões dos organismos estatais são tomadas em face de uma economia globalizada e multinacional, os Estados vêm perdendo o papel de protagonistas na criação das normas jurídicas ${ }^{58}$. As pressões e as exigências dos agentes econômicos para a flexibilização das regras locais que muitas vezes embaraçam o exercício de suas atividades, conduzem a exemplos concretos de unificação e de internacionalização do Direito como nunca se viu antes.

A breve análise desse fenômeno se limitará ao direito processual.

Numa visão otimista, pode-se dizer que essa internacionalização remonta às aspirações da antiga civilização grega por um direito natural e comum a todos os povos, culminando na Declaração Universal dos Direitos Humanos, o texto principal sobre a proteção dos direitos e liberdades fundamentais ${ }^{59}$.

Como não poderia deixar de ser, duas relevantes iniciativas para a criação de um direito processual transnacional partiram da maior potência econômica do mundo. A primeira, elaborada pela International Bar Association, resultou num projeto que estabelece princípios comuns para os litígios de natureza mercantil, mais precisamente os relacionados ao comércio internacional, tratando da litispendência, das medidas de urgência e da conservação de direitos, da prova do direito estrangeiro e da prescrição, entre outros temas.

A segunda e mais ousada iniciativa norte-americana cuida da harmonização mundial das regras processuais civis no que toca aos litígios transnacionais ${ }^{60}$. Em parceria com o Unidroit, o American Law Institute conseguiu que o seu projeto, fruto da elaboração e da redação majoritária de juristas da common law, integrasse o programa de trabalho do primeiro instituto desde 1999. Com exceção da Itália, representada por Michele Taruffo, Elisabetta Silvestri e Federico Capri, os países da família romano-

\footnotetext{
${ }^{58}$ Não há dúvida de que o Estado ainda legisla, e muito. "Mas passou a fazê-lo, agora, e esse é o fato novo digno de nota, diminuído em seu poder de intervenção e, muitas vezes, constrangido a compartilhar sua titularidade de iniciativa legislativa com diferentes forças que transcendem o nível nacional. Ou seja: limitado em suas políticas fiscais, em seus instrumentos de direção e em suas estratégias de planejamento; obrigado a levar em conta antes o contexto econômico-financeiro internacional do que as próprias pressões, anseios, expectativas e reivindicações nacionais" (José Eduardo Faria. $O$ direito na economia globalizada, p. 141).

${ }_{59}$ A perspectiva é de Serge Guinchard, que ainda se refere a essa unificação como forma de compensar, por meio do direito universal, as duas grandes guerras do Século XX: "la mondialisation du droit, maintes fois soulignée, accompagne la mondialisation de l'economie et traduit l'aspiration à un droit commun, notamment dans le domaine de la justice et du procès (y compris le procès arbitral), comme si les hommes cherchaient à compenser, par le droit, vecteur morale, la mondialisation des guerres, par deux fois au cours du XXe. siècle" (Droit processuel, p. 267).

${ }^{60}$ Transnational Rules of civil Procedure.
} 
germânica tiveram escassa participação nesse projeto, cuja aprovação dependerá da remoção de dois enormes obstáculos: a conciliação de dois sistemas jurídicos bem diferentes (common e civil law) ${ }^{61}$ e a superação do receio (em especial europeu) de um domínio norte-americano e de seus institutos como o júri civil e o regime probatório da discovery ${ }^{6263}$.

$\mathrm{Na}$ América Latina as tentativas de uniformização do processo civil foram muito mais frutíferas.

Elaborado pelo Instituto Ibero-Americano de Direito Processual e aprovado em 1988, o Código de Processo Civil Modelo é marcado pela oralidade preconizada pela doutrina de Chiovenda e prevista no Código austríaco de $1895^{64}$. Os poderes instrutórios do juiz são reforçados e a concentração de atos em uma ou duas audiências, no máximo, é a tônica do procedimento. Já se previa a tutela dos interesses difusos, legitimando qualquer interessado em pleiteá-la, mas sob o controle da representatividade adequada pelo juiz. O Código Geral de Processo do Uruguai de 1989 é cópia quase fiel do Código Modelo.

Em relação aos direitos coletivos, o citado Instituto aprovou em 2004 um projeto de iniciativa dos professores brasileiros Ada Pellegrini Grinover, Kazuo Watanabe e Antonio Gidi, tornando seu documento oficial o Código Modelo de Processos Coletivos para Ibero-América. Disposto em 41 artigos, o texto mostra o anseio de seus autores em criar um processo civil social, respeitando as peculiaridades de cada país, e atento às experiências das nações latino-americanas na tutela dos direitos coletivos. Embora tenham sido consideradas as class actions norte-americanas e as ações coletivas brasileiras, o Código delas se afastou em alguns momentos para propiciar um sistema original.

\footnotetext{
${ }^{61}$ Steven H. Gifis define de modo bastante simples a common law como o sistema da jurisprudência, baseado nos precedentes judiciais, em contraste com a civil law, oriunda do Codex Justinianus e fundada nas leis escritas (Law dictionary, verbetes roman law e common law). Vale lembrar, contudo, que nos Estados Unidos houve um certo distanciamento das raízes da common law inglesa, tanto que há estados com codificação civil e mesmo com as características romano-germânicas, como é o caso da Lousiana (v. Guido Fernando Silva Soares. Common law: introdução ao direito dos EUA, p. 52).

${ }^{62}$ Pelo qual permite-se que os litigantes munam-se diretamente de provas, em especial documentos, tanto do adversário como de terceiros e, aos quais, normalmente, não teriam acesso.

${ }^{63}$ Serge Guinchard chega a ser sarcástico com o projeto, dizendo que este reflete o dito popular: "O que é bom para a América é bom para o resto do mundo". Ao impor ao juiz local o abandono da lex fori pelas regras estabelecidas no projeto, o citado autor mostra todo o seu nacionalismo e conclui que há uma tentativa de "mettre sur pied une lex mercatoria procédurale, dont l' inconvénient majeur est d'être très éloignée de la culture judiciaire continentale, romano-germanique et française" (Droit processuel, p. 273/274).

${ }^{64}$ Em 1983 o legislador austríaco tornou a audiência preliminar facultativa e em 2002 a extinguiu sob a justificativa de que deveria acelerar o procedimento (a informação é J.C. Barbosa Moreira em La significación social de las reformas procesales, p.155).
} 
A Comunidade Européia prossegue com o projeto de aproximar as legislações processuais de seus países, dando continuidade ao trabalho iniciado pela Comissão do Código Judiciário Europeu, sob a direção de Marcel Storme e que publicou em 1994 um estudo comparativo sobre as normas processuais dos Estados membros, os quais deverão aprovar por unanimidade as regras comuns propostas para que sejam aplicadas em toda a Comunidade ${ }^{65}$.

A par desses exemplos de unificação ou de tentativas de internacionalizar o direito processual, observa-se nos últimos anos um constante intercâmbio legislativo de institutos da common law e da civil law a reduzir a dicotomia entre esses sistemas jurídicos.

Cronologia à parte, o instituto que mais chama a atenção pela boa influência, mas concomitantemente pelo mau desempenho em diversas Comarcas e Seções Judiciárias do território nacional é o small claim courts, batizado pela primeira vez no Brasil em 1984, de Juizados de Pequenas Causas ${ }^{66}$ e que têm como princípios informadores, entre outros, a gratuidade, a celeridade, a informalidade, a economia processual e o estímulo à conciliação ${ }^{67}$. Embora fiéis aos anseios de Mauro Cappelletti de tornar o acesso à Justiça uma realidade aos necessitados, revelam-se na prática diária de muitos locais em verdadeira negação de direitos ${ }^{68}$.

Acentuam o distanciamento entre os ideais legislativos e a realidade forense as raízes culturais e o misoneísmo de boa parte dos profissionais do Direito. A cultura romano-canônica, em especial a brasileira, reluta em aquiescer com os meios

${ }^{65}$ Cf. Serge Guinchard. Droit processuel, p. 275/276. Para uma visão completa dos instrumentos europeus de cooperação em matéria processual criados desde o Tratado de Amsterdã em 1999, v. Italo Augusto Andolina. Il 'giusto processo' nell'esperienza italiana e comunitaria. RePro 126, p. 95/113.

${ }^{66}$ Hoje Juizados Especiais Cíveis e Criminais pela Lei no $9.099 / 95$ e Juizados Especiais Federais pela Lei $\mathrm{n}^{\mathrm{o}} 10.259 / 2001$.

${ }^{67}$ Lembram Ada Pellegrini Grinover e Kazuo Watanabe que o modelo japonês da conciliação promovida por membros da comunidade foi uma das importantes inspirações quando concebidos no Brasil os Juizados Especiais (Recepção e transmissão de institutos processuais civis, p. 149).

${ }^{68}$ O Juizado Especial Cível de uma Comarca do interior do Estado de São Paulo em que trabalhamos tinha cerca de 15.000 processos em andamento no final de 2006. Não havia juiz exclusivo para atender a esse volume de serviço, o número de funcionários era insuficiente e uma audiência de instrução e julgamento só seria realizada um ano depois de sua designação. Tal situação ainda se repete em outras Comarcas paulistas, especialmente aquelas que não dispõem de um magistrado titular da Vara dos Juizados. Com razão, lembra Paulo Hoffman que o Juizado Especial "na grande maioria das Comarcas, veio representar somente mais encargo e acúmulo de serviço aos juízes de $1^{\circ}$ grau, obrigados a atuar nesses juizados, normalmente após o expediente normal em suas respectivas varas, sem a devida contraprestação. Outro fator que não permite um melhor aproveitamento dos Juizados está na escolha e falta de treinamento dos conciliadores, que são, muitas vezes, advogados sem grande representatividade ou sucesso profissional ou, até mesmo, estudantes de Direito, o que impede um melhor aconselhamento das partes com vistas à conciliação, em razão da falta de experiência forense" (Razoável duração do processo, p. 134). 
alternativos de solução de conflitos. Para um cidadão comum e para alguns bacharéis em ciências jurídicas, defrontados diuturnamente com um indecifrável código legislativo em constante profusão, a única resolução justa de seu conflito só poderia ser outorgada pela autoridade investida da função constitucional de dirimi-lo. De nada lhes servem árbitros remunerados por uma das partes, conciliadores e outros tantos profissionais - ainda que muito bem intencionados - se a palavra final de dizer o Direito só pode ser pronunciada por um dos protagonistas daquele demorado episódio.

Dados estatísticos dos mutirões mensais de conciliação realizados num dos mais movimentados Fóruns do mundo, bem ilustram que o êxito dos meios alternativos de solução de litígios em nossa sociedade é longínquo, pelo menos para as demandas já em andamento: de setembro de 2004 a junho de 2007, 34,1 mil processos passaram pelo Setor de Conciliação do Fórum João Mendes Jr. na Capital paulista; 20,1 mil audiências foram realizadas; mas, em apenas $21,55 \%$ dos casos houve êxito na transação dos litigantes ${ }^{69}$. E não há dados do efetivo cumprimento de todos esses acordos, tampouco se ao retornarem às Varas de origem, necessitaram tais processos de outras determinações judiciais para a efetivação das transações celebradas.

De outra banda, institutos da civil law são incorporados pela legislação recente de países da common law e o exemplo mais nítido dessa assimilação de modelos alienígenas pode ser visto nas Civil Procedure Rules inglesas de 1998. Houve sensível mitigação do sistema $a d v e r s a r i a l^{70}$, conferindo-se ao juiz poderes de direção e instrução do processo que até então não detinha, como o controle da pertinência e da produção da prova pericial.

A adoção de uma norma processual multinacional é obstada pelas diferentes culturas e tradições jurídicas das nações. No entanto, o intercâmbio de institutos é uma realidade motivada por aspirações comuns: a celeridade processual e a efetividade das decisões judiciais. É possível colher bons frutos com as técnicas estrangeiras, mas sempre com o cuidado de adaptá-las às peculiaridades do sistema em que serão

\footnotetext{
${ }^{69}$ Fonte: sítio do Conselho Nacional de Justiça. Para os casos chamados de "extraprocessuais", porém, o percentual é animador: $73,85 \%$ de transações. Já o índice de conciliação em segundo grau na justiça paulista entre janeiro e setembro de 2007 foi de 28,36\% (fonte: Diário Oficial da Justiça, edição de $10 / 10 / 2007)$.

${ }^{70}$ Sistema alvo de inúmeras críticas por sua lentidão e por deixar ao talante das partes o andamento da causa e da instrução.
} 
empregadas para que a inovação não se revele anódina ou, pior, destrua eficientes institutos processuais do país em que é incorporada açodadamente ${ }^{71}$.

\subsection{As injunctions e a tutela inibitória italiana.}

Em 1974, Aldo Frignani, professor de Direito Privado Comparado da Universidade de Torino, lançou importante obra sobre esses dois institutos do direito estrangeiro e que servem de importante referência para os provimentos judiciais brasileiros previstos no art. 84 do Código de Defesa do Consumidor.

As injunctions representam um instrumento de aplicação geral para uma eficiente tutela preventiva em relação aos mais variados tipos de ilícito e podem ser definidas como a ordem da Corte dirigida a uma pessoa para fazer ou não fazer algo. Apresenta dois aspectos: positivo (mandatory injunction) e negativo (prohibitive injunction). Nos Estados Unidos da América são extremamente importantes na defesa dos direitos civis, sociais e políticos.

O campo de autuação das injunctions é a equity, isto é, o conjunto de regras aplicadas pelas Cortes e que seguiam as exigências de uma justiça natural, permeada pela ética e pela eqüidade. Age sem a previsão abstrata para regular o caso concreto e há simplicidade nas normas processuais, que permitem a adoção de medidas variadas a fim de propiciar à parte a obtenção eficaz de seu direito.

Contrapondo-se aos tecnicismos e à rigidez da common law, a equity confere aos juízes o poder de criar os mais diversos remédios jurídicos, de modo que a cada situação concreta corresponda um meio de tutela adequado. Também contrasta com as medidas reparatórias, possibilitando que o juiz adote providências subsidiárias ou alternativas em face daquelas já previstas na lei.

Com o fim do dualismo entre as Cortes de common law e de equity, intensificou-se a aplicação das injunctions nas primeiras, especialmente em ilícitos extracontratuais (torts), propriedade comercial e direitos da personalidade.

Há injunctions concedidas depois do julgamento de mérito (final) e aquelas emitidas com características de um provimento de urgência ou cautelar (preliminary), no escopo de manter a situação fática e prevenir ulteriores violações a um direito.

\footnotetext{
${ }^{71}$ Para as conseqüências prejudiciais do "deslumbramento ingênuo que impele à imitação acrítica de modelos estrangeiros", mas sem descartar a utilidade do estudo do direito comparado, v. José Carlos Barbosa Moreira. O futuro da justiça: alguns mitos, "in” Temas de direito processual, 8a série, p. 7/10.
} 
A doutrina anglo-americana afirma que o pressuposto mais importante para a concessão da injunction é que não seja adequada a via das perdas e danos. Assim, não será emitida tal ordem se o ilícito já foi cometido (e exaurido) no passado e se não se verificar o risco de repetição ou a intenção do agente em praticá-lo no futuro.

A opção entre a injunction ou as perdas e danos é ato que se reveste de discricionariedade judicial, que levará em conta não apenas o aspecto econômico, mas também o jurídico da medida a ser implantada. O poder discricionário do magistrado obviamente não significa o arbítrio, mas sim "una discrezionalità che deve essere esercitata giuzialmente, secondo i principi che sono stati stabiliti dai binding precedents" ${ }^{\prime 72}$. Fará o juiz um balance of hardship e não concederá a injunction se os danos forem de pequena monta, o ilícito tiver cessado, houver dificuldade ou inutilidade no cumprimento da sentença ${ }^{73}$ ou se o demandado assumir o compromisso formal perante a Corte de se abster do comportamento lesivo que lhe é imputado.

Não há um princípio ou regra geral para a concessão de injunctions, mas são comuns nos Estados Unidos as experimental orders em casos de danos ao meio ambiente. Um exemplo dessa medida é a designação, pela Corte, de um especialista para atuar no estabelecimento poluidor ou ruidoso a fim de verificar se a fumaça, poluentes, barulhos e outros agentes nocivos podem ser diminuídos ou eliminados com a aplicação de recursos técnicos modernos.

Já a inibitória italiana pressupõe um perigo e é essencialmente preventiva. Não depende da ocorrência de um dano e consiste no comando do juiz que tem como conteúdo uma obrigação de colocar imediatamente fim a uma atividade ilícita ou de não permitir que venha a ocorrer. A lei italiana usa as locuções cessação e inibição quando trata da ação inibitória, compreendendo com isso duas situações distintas: a ordem judicial que impõe a parada de uma atividade e uma ordem para que ela não continue.

Cabíveis as perdas e danos para o ilícito passado, a ação monitória se presta à remoção do ilícito iminente ou futuro, mas não se trata da aplicação de uma sanção para quem ainda vai cometer um ilícito, já que o provimento judicial é uma aplicação ou especificação de uma obrigação preexistente contida no ordenamento jurídico e que impõe ao sujeito determinado comportamento. Em outras palavras, a ordem do juiz não cria uma obrigação nova ou diferente daquela que o destinatário transgrediu ou está para transgredir.

\footnotetext{
${ }^{72}$ Aldo Frignani. L'injunction nella common law e l'inibitoria nel diritto italiano, p. 156.

${ }^{73}$ Inútil, por exemplo, uma ordem para não derrubar árvores se estas já foram abatidas.
} 
No sistema italiano há dois tipos de tutela inibitória: uma final ou definitiva e outra preliminar, temporária ou cautelar. Embora o legislador não se refira à inibitória final, a sua existência é inequívoca dada a contraposição com as medidas concedidas no curso da demanda e aquelas atreladas a provimentos de urgência e emitidas com base no poder geral de cautela do juiz. A inibitória final consubstancia uma ordem que o juiz encaminha à parte para fazer ou não fazer algo depois de uma decisão sobre o mérito da demanda. A provisória é subsidiária da inibitória final, já que antecipa os efeitos desta e em regra se destina a congelar uma situação a fim de evitar que as conseqüências do ilícito continuem ou se repitam.

Ao contrário do juiz da common law na concessão de injunctions, o juiz italiano não pode negar a inibitória se prevista para a situação concreta, sob o argumento de que será extremamente onerosa ao destinatário da ordem. Não há, portanto, aquela liberdade de atuação do julgador, uma vez que a inibitória não é um remédio abstrato escolhido de forma aleatória e sim um provimento aderente ao fato concreto e adaptável a diversas exigências. Impõe-se ao juiz não apenas a ordem de cessar o ilícito em abstrato, como também individualizar com precisão o ilícito e ordenar a cessação com específica referência à hipótese em exame.

\section{Os provimentos judiciais brasileiros.}

\subsection{Natureza e alcance.}

Na sua redação primitiva o Código de Processo Civil não utilizava o vocábulo provimento para designar uma medida ou providência ordenada pelo juiz. A palavra era reservada aos recursos, significando que o órgão ad quem, ao verificar a presença dos pressupostos de admissibilidade, apreciava o mérito do recurso, dando-lhe ou não provimento.

Com a reforma da Lei $\mathrm{n}^{\mathrm{o}} 10.358 / 2001$, estabeleceu o legislador o dever das partes e de todos aqueles que de qualquer forma participem do processo em "cumprir com exatidão os provimentos mandamentais e não criar embaraços à efetivação de provimentos judiciais, de natureza antecipatória ou final". ${ }^{74}$

\footnotetext{
${ }^{74}$ Art. 14, V, do CPC.
} 
Em conseqüência, incorporou-se ao direito positivo o provimento como sinônimo de pronunciamento do juiz, de decisão que resolve alguma questão surgida no processo ou que emite um comando ${ }^{75}$. Por outro lado, não são provimentos judiciais os atos materiais subseqüentes ou complementares ao pronunciamento do juiz e, a cargo deste ou dos auxiliares do juízo (p. ex. a expedição e a assinatura de um mandado, a intimação da parte), razão pela qual o artigo 162 do Código de Processo Civil é equívoco ao restringir os atos judiciais aos provimentos (sentenças, decisões interlocutórias e despachos), pois na prática o juiz realiza, além dos já citados, outros atos no curso do processo (p.ex., designa e preside as audiências, colhe a prova), que não são pronunciamentos e nem resolvem questões.

Alvo de inúmeras críticas da doutrina, as modalidades de provimentos judiciais definidas pelo art. 162 do Código de Processo Civil de 1973 tinham por escopo simplificar o complexo sistema de recursos do Código de 1939, sujeitando a sentença à apelação e as decisões interlocutórias ao agravo, à medida que tornara irrecorríveis os despachos, também rotulados de despachos de mero expediente. Na redação primitiva do $\S 1^{\circ}$ do citado artigo, a sentença era "o ato pelo qual o juiz põe termo ao processo, decidindo ou não o mérito da causa", enquanto que a decisão interlocutória era "o ato pelo qual o juiz, no curso do processo, resolve questão incidente" ( $\left.\S 2^{\circ}\right)$. Adotava-se, por conseguinte, o critério topológico e não se considerava o conteúdo desses atos judiciais.

A Lei $\mathrm{n}^{\mathrm{o}} 11.232 / 2005$ alterou o $\S 1^{\mathrm{o}}$ do artigo 162 e agora chama de sentença “o ato do juiz que implica alguma das situações previstas nos arts. 267 e 269 desta Lei”, ou seja, que decidir ou não o mérito da demanda, encerrando uma fase do processo (a cognitiva) em primeiro grau de jurisdição ${ }^{76}$.

Não é nosso propósito mostrar os acertos ou desacertos do legislador com a sua opção de conceituar sentenças, decisões interlocutórias e despachos ${ }^{77}$. Importa é que, independentemente do momento processual ou da forma, os três poderão em tese

\footnotetext{
${ }^{75}$ Para Cândido Rangel Dinamarco, provimentos judiciais "são declarações de vontade do Estado-juiz, às vezes acompanhadas de alguma determinação no sentido de realizar ou omitir uma conduta" (Instituições de direito processual civil, vol. II, p. 491).

${ }^{76}$ Para o novo conceito de sentença e as suas implicações, v. José Carlos Barbosa Moreira. A nova definição de sentença, p. 268/276.

${ }^{77}$ E.D. Moniz de Aragão registra com bastante perspicácia que na prática forense há despachos que "excedem o âmbito do mero expediente" e que poderão acarretar ônus ou lesões às partes, comportando assim o recurso de agravo, apesar da vedação do art. 504 do CPC. Propõe a seguinte solução: "todos os despachos que visem unicamente à realização do impulso processual, sem causar qualquer lesão ao direito das partes, serão de mero expediente" (Comentários ao CPC, p. 65/66).
} 
consubstanciar provimentos judiciais. Para tanto, basta que contenham uma decisão precedida de um juízo de valor e que sejam capazes de afetar a esfera jurídica do destinatário.

\subsection{A polêmica da classificação.}

Tema extremamente espinhoso e que divide a doutrina contemporânea diz respeito à classificação das sentenças, espécie de provimento judicial que segundo a atual dicção do art. $162, \S 1^{\circ}$, do Código de Processo Civil, resolve ou não o mérito da demanda.

Ressalvados poucos autores, a classificação ternária ${ }^{78}$ das sentenças de conhecimento (declaratórias, constitutivas e condenatórias) foi larga e incondicionalmente aceita pelos estudiosos durante anos. A sentença declaratória (ou meramente declaratória) se destina a solucionar uma crise de incerteza jurídica, declarando a existência (ou a inexistência) de um fato ou ato relevante. Pela sentença constitutiva, o juiz cria, extingue ou modifica relação ou situação jurídica. Já as sentenças condenatórias contêm dois elementos característicos: a declaração da existência de um direito e a aplicação de uma sanção, que sujeitava posteriormente o devedor a medidas executivas para solucionar eventual inadimplemento ${ }^{79}$.

Considerada satisfatória e capaz de agrupar todas as modalidades de sentenças e, conseqüentemente, de provimentos judiciais, a classificação ternária passou a ser questionada com mais intensidade no Brasil a partir da vigência do artigo 84 do Código de Defesa do Consumidor e da Lei $n^{\circ}$ 8.952/94, que alterou o regime da execução das obrigações de fazer e de não fazer ${ }^{80}$.

O surgimento de direitos cuja tutela reclamava medidas mais efetivas de preservação e restauração do que as tradicionais perdas e danos, bem como a insuficiência da sentença que, depois do longo itinerário do processo de conhecimento, simplesmente declarava o direito e impunha uma sanção ao vencido, obrigando o seu adversário e vencedor a percorrer todas as fases do processo executivo para receber soma em dinheiro, reavivaram a classificação de Pontes de Miranda, inspirada na

\footnotetext{
${ }^{78}$ E não "trinária", palavra inexistente em nosso vernáculo.

${ }^{79}$ Cf. Liebman, Manual, p. 236/237.

${ }^{80}$ É certo que a Lei no $7.347 / 85$ (Ação Civil Pública) já previa no art. 11 a tutela específica das obrigações de fazer ou não fazer; mas, sem as peculiaridades e o rol de medidas dos arts. 84 do CDC e 461 do CPC.
} 
doutrina alemã, que acrescentava às espécies acima mencionadas a sentença mandamental e a sentença executiva ${ }^{81}$.

Em linhas gerais, para Pontes de Miranda na sentença mandamental o juiz não condena nem constitui, mas sim manda, isto é, emite uma ordem a ser cumprida imediatamente pelo destinatário (pessoa física ou jurídica, autoridade ou não), ao passo que na sentença executiva é retirado algo do devedor e transferido ao patrimônio do credor $^{82}$. A sentença executiva, ao contrário da condenatória, dispensa a instauração de processo de execução, visto que já tem essa força.

Lembre-se que o referido autor classificava as sentenças a partir de sua eficácia predominante, conferindo-lhes pesos ou cargas declarativas, condenatórias, constitutivas, executivas e mandamentais, numa série decrescente de cinco a um. Assinalava que nenhuma sentença era totalmente pura, já que sempre se poderia encontrar em cada uma das espécies, cargas das outras, mas o peso predominante seria o responsável por enquadrá-las nas categorias citadas.

Os adeptos da teoria quíntupla criticam a teoria tradicional por desconsiderar as diferenças dos fenômenos da pretensão, da ação de direito material e da ação de direito processual $^{83}$, enquanto que a corrente ternária suscita profundas dúvidas quanto aos traços distintivos das ações executivas lato sensu e das ações mandamentais ${ }^{84}$.

Nenhuma das classificações apontadas está imune a críticas e indagações sem respostas convincentes, tampouco poderá ser considerada como a verdade absoluta e inquestionável ${ }^{85}$. Pecam aqueles que iniciam a classificação do provimento à luz de seu conteúdo e, às vezes, terminam por enquadrá-lo em face de seus efeitos. Como observa Barbosa Moreira, "podemos classificar as sentenças de acordo com o conteúdo, ou de

\footnotetext{
${ }^{81}$ Não era costume de Pontes de Miranda empregar a expressão sentença executiva "lato sensu" em contraposição a uma sentença executiva "stricto sensu", como observado por José Carlos Barbosa Moreira (v. Sentença executiva? p. 147 e seguintes).

${ }^{82}$ Tratado das ações, Tomo I, p. 135.

83 "Quando se diz que as ações e sentenças podem ser declaratórias, constitutivas e condenatórias, está-se a descrever a ação de direito material, a ação firmada pelo autor, que pode inclusive, não existir, enquanto a outra ação, aquela dirigida ao Juiz e que desencadeia a jurisdição, certamente terá existido" (Ovídio A. Baptista da Silva. Teoria geral do processo civil, p. 251/251).

${ }^{84}$ Sobre o artificialismo e os equívocos da doutrina de Pontes de Miranda, embora aceitando a subclasse das ações mandamentais, v. José Carlos Barbosa Moreira. Questões velhas e novas em matéria de classificação de sentenças, " in" Temas de direito processual, $8^{a}$ série, p. 129/140.

${ }^{85}$ Como pondera Kazuo Watanabe: "Os conceitos e as categorias doutrinárias existem no plano lógico, como instrumentos destinados à melhor compreensão dos fenômenos. Bem por isso, não podem ser submetidos a um culto irrefletido, como se tivessem existência per se. A significação e o alcance de cada um deles variam segundo o ângulo visual e o plano de observação do processualista" (Da cognição no processo civil, p. 90).
} 
acordo com os efeitos. $\mathrm{O}$ que decididamente não podemos é passar, no meio do caminho, de um critério a outro" ${ }^{\$ 6}$.

Havia mesmo de ser posto em xeque-mate o efeito singular da tradicional sentença condenatória, qual seja, o de apenas produzir um título executivo, condição sine qua non para o credor iniciar outro processo no escopo de satisfazer (e não só ver reconhecida) a obrigação declarada no processo de conhecimento. Além disso, nem todas as violações de direitos, sobretudo os coletivos, são prevenidas, obstadas ou reparadas com a condenação do ofensor ao pagamento de soma em dinheiro ${ }^{87}$, a pretensão mais freqüente veiculada nas demandas condenatórias.

A exigência de uma tutela mais efetiva e mais adequada fez com que o direito processual, sintonizado com consagrada máxima Chiovendiana ${ }^{88}$, criasse novos mecanismos de satisfação do direito material sem o qual, aliás, o processo não teria razão de ser, enquanto método de trabalho ou de instrumento para a realização de direitos que é.

E a inovação ocorreu justamente com as técnicas para a tutela dos direitos coletivos nas obrigações de fazer e de não fazer. Depois de estabelecer no art. 83 a admissibilidade de todas as espécies de ações para a tutela dos direitos e interesses previstos na Lei no 8.078/90, o legislador preconizou que "na ação que tenha por objeto o cumprimento da obrigação de fazer ou não fazer, o juiz concederá a tutela específica da obrigação ou determinará providências que assegurem o resultado prático equivalente ao do adimplemento".

A leitura atenta desses dispositivos legais conduzirá o intérprete, independentemente de sua opção pelas teorias acima expostas de forma muito resumida, à conclusão de que é amplo o espectro dos provimentos judiciais para a tutela dos direitos coletivos e que, mais relevante do que classificá-los conforme a corrente ternária ou a quíntupla é saber quais são esses provimentos diferenciados e quando poderão ser empregados.

\footnotetext{
${ }^{86}$ Questões velhas e novas..., p. 141.

87 De pouca (para não dizer de nenhuma) utilidade prática condenar quem degrada o meio ambiente ao pagamento de determinada quantia, quando a continuidade da ofensa pode ser prontamente obstada e medidas compensatórias (p. ex. reflorestamento, instalação de filtros) podem ser implantadas.

${ }^{88}$ Il processo deve dare per quanto possibile praticamente a chi ha un diritto tutto quello e proprio quello ch'egli ha diritto di conseguire.
} 
É certo que o contemporâneo legislador processual não ressuscitou a vetusta teoria imanentista do direito de ação ${ }^{89}$, em que esta e o próprio direito material eram apenas as duas faces da mesma moeda, mas é inegável que procurou dotar o sistema processual de remédios mais eficientes de acordo com o direito material invocado pelo autor da demanda, sem se preocupar com uma classificação dogmática ${ }^{90}$ e processual das técnicas para a tutela dos novos direitos. Tanto é verdade, que não se fala em condenação ou execução, mas sim em cumprimento de obrigação de fazer ou de não fazer, cuja gênese pertence ao direito material e não ao direito processual.

\subsection{Os provimentos segundo a situação de direito material.}

Poder-dever do Estado consiste a jurisdição não somente em dizer o direito, mas também em atuá-lo concretamente. É de Chiovenda que se colhe a lição segundo a qual a atividade jurisdicional é substitutiva e tem por escopo a atuação do direito. Para Liebman, a jurisdição se desenvolve em dupla direção, mediante cognição e execução. Na cognição, o juiz age como um historiador, reconstruindo fatos passados e valorandoos à luz do ordenamento vigente a fim de formular uma regra jurídica para disciplinar o caso concreto, enquanto na execução dá "atuação prática e efetiva àquilo que a lei dispõe para os casos concretos" 91 .

A aspiração principal do processualista contemporâneo é encurtar ao máximo a grande distância que separa o ideal do legislador do real do quotidiano forense. Inevitavelmente, tal anseio deve conduzir a um pragmatismo (e não a um praxismo). Afinal, o processo deve ser um processo de resultados e não um complexo ininteligível de princípios e dogmas distantes da realidade.

Partindo dessas e de outras premissas, Luiz Guilherme Marinoni esboça uma nova classificação das tutelas, mas salienta que não pretende restabelecer a teoria civilista da ação, mantendo-se fiel à teoria do direito abstrato. Depois de percorrer a doutrina alienígena, em especial a italiana, arrola as seguintes modalidades: ressarcitória, reintegratória, tutela de obtenção e de restituição de coisa, tutela específica

\footnotetext{
${ }^{89}$ Também chamada de teoria civilista, cujo precursor foi o jurisconsulto Celso, para o qual nihil aliud est actio quam ius, quod sibi debeatur, in judicio persequendi (a ação nada mais é que o direito de pedir em juízo o que nos é devido). Para a leitura e a compreensão dos artigos $5^{\circ}, \mathrm{XXXV}$, da Constituição Federal e 75 do Código Civil de 1916 sem essa visão imanentista, v. Kazuo Watanabe. Código brasileiro de defesa do consumidor comentado pelos autores do anteprojeto, p. 836/837.

${ }^{90}$ Aliás, uma das diretrizes do movimento reformista do Código de Processo Civil, iniciado em 1992 é justamente deixar de lado "divergências de ordem doutrinária ou meramente acadêmicas".

${ }_{91}$ Manual de direito processual civil, p. 21.
} 
do adimplemento da obrigação contratual de fazer e de entregar coisa, tutela específica do dever legal de fazer e tutela inibitória ${ }^{92}$.

Respeitada a erudição do consagrado autor, contrapõe-se a qualquer tentativa nova ou antiga de classificação das tutelas, a necessidade de eliminar divergências doutrinárias estéreis e voltar os olhos para as técnicas de atuação prática do direito material $^{93}$.

Com a clareza e a objetividade que marcam seu profícuo trabalho, José Carlos Barbosa Moreira oferece um esquema simples e ao mesmo tempo completo para ordenar as técnicas de efetivação dos provimentos jurisdicionais. A partir do postulado da "maior coincidência possível", isto é, o de que o "processo funciona tanto melhor quanto mais se aproximar o seu resultado prático daquele a que levaria a atuação espontânea do direito" "94, situa a problemática da execução forçada à luz da natureza da prestação devida ao vencedor da demanda, reunindo as obrigações do vencido em: $1^{\circ}$ ) dar algo; $2^{\circ}$ ) fazer algo; $3^{\circ}$ ) impedir que algo aconteça.

Para o presente estudo interessam as duas últimas modalidades, já que a efetivação da tutela de dar algo (inclusive dinheiro) ou é objeto de ampla regulamentação legal ${ }^{95}$ ou é conseguida por meio da simples emissão de mandado judicial de reintegração de posse ou de busca e apreensão, conforme se tratar de bem imóvel ou móvel. Além disso, a condenação ao pagamento de quantia certa em demandas coletivas é de rara ocorrência em virtude das características já examinadas dos interesses metaindividuais, ao passo que nas obrigações de fazer ou não fazer a tutela específica é a prioritária, admitindo-se apenas em caráter subsidiário a conversão em perdas e danos se por elas optar o autor ou se inviabilizadas sob o aspecto material aquelas obrigações ${ }^{96}$.

Em conseqüência, o estudo se concentrará nos provimentos para a efetivação das obrigações de fazer e de não fazer nas demandas coletivas.

\footnotetext{
${ }^{92}$ Tutela inibitória, p. 485/46.

93 "Ao invés de perder tempo digladiando sobre qual classificação de sentenças é mais útil à efetividade do processo, melhor voltar a atenção para outros aspectos da execução ou efetivação da tutela condenatória: aperfeiçoar qualitativamente os meios e formas de tutela executiva em função da natureza da obrigação (dar, fazer, não-fazer, fungível, infungível), simplificá-los para tornar mais célere a execução e ampliar quantitativamente as hipóteses de atuação prática da sanção executiva, realizada pela forma específica ou por expropriação" (José Roberto dos Santos Bedaque. Efetividade do processo e técnica processual, p. 567).

${ }^{94}$ Tendências na execução de sentenças e ordens judiciais, "in” Temas..., $4^{\mathrm{a}}$ série, p. 215.

${ }^{95}$ V. arts. 475 e 646 a 724 do Código de Processo Civil, que tratam do cumprimento de sentença condenatória para o pagamento de soma em dinheiro e da execução por quantia certa contra devedor solvente, além de disciplinar os instrumentos para a expropriação de bens do devedor.

${ }^{96}$ É o que determina o art. 84, "caput", do Código de Defesa do Consumidor.
} 


\subsection{Alguns provimentos do direito comparado.}

Meios para se conseguir a tão decantada e almejada efetividade do processo, os provimentos jurisdicionais diferenciados ${ }^{97}$ são objeto de estudos de juristas de vários países há anos.

Sob a coordenação de Giuseppe Tarzia, realizou-se em outubro de 1984 um encontro internacional na Universidade de Milão, cujo tema eram as decisões de caráter provisório e urgente admissíveis nos ordenamentos jurídicos dos países participantes e as eventuais sanções para o descumprimento dessas medidas judiciais.

O encontro deu origem a um livro ${ }^{98}$, no qual foi inserida palestra da Professora Ada Pellegrini Grinover proferida posteriormente na Faculdade de Jurisprudência de Milão e coube a Vittorio Denti a elaboração de um relatório geral em que identificou pontos comuns e peculiares nos sistemas jurídicos examinados.

Concluiu que embora não haja uma correlação perfeita e necessária entre o problema da efetividade e os procedimentos executivos, a falta de efetividade das decisões judiciais ${ }^{99}$ pode ser um sintoma da ineficácia das vias executivas tradicionais. No que toca à execução por quantia certa, destacou que a função clássica da execução forçada (colocar os bens do devedor sob as mãos do Judiciário para vendê-los e pagar o credor com o produto da venda) foi suplantada pela evolução social e econômica, num contexto em que os bens já não têm o papel estático de antes, tornando a penhora muito mais um meio para constranger o devedor a pagar, do que um meio de satisfazer por completo o credor.

Ganham importância em todos os sistemas jurídicos as obrigações destituídas de um caráter patrimonial direto, ou seja, aquelas em que a conversão em perdas e danos não representará a tutela efetiva e adequada do direito ameaçado ou violado. Inserem-se nesse campo não só os direitos individuais da personalidade (nome, privacidade, identidade), mas também os direitos coletivos. E é justamente nesse campo

\footnotetext{
${ }^{97}$ Compreendemos em provimentos diferenciados todo tipo de ordem judicial que extrapole o âmbito das clássicas categorias (condenação, declaração e constituição). Englobam, portanto, as medidas de subrogação, de apoio, de estímulo e de coerção.

${ }^{98} L^{\prime}$ effectivité des decisions de justice (journées françaises), T. XXXVI. Paris : Economica, 1985.

${ }^{99}$ A efetividade das decisões é um tema clássico da sociologia jurídica, tanto quanto a efetividade das próprias normas jurídicas, assinala o autor.
} 
das obrigações não pecuniárias que os provimentos diferenciados e os meios de coerção e de execução indireta assumem destaque.

Para Vittorio Denti, estamos diante de um fenômeno que pode ser chamado de declínio da força da coisa julgada. Para o credor importa a eficácia da decisão, independentemente de ser provisória ou com a autoridade da res judicata. O fato é mais relevante do que o direito, de modo que à parte contemplada com um provimento, pouco interessa a possibilidade de ser revertida no futuro a decisão. Os sistemas da civil e da common law se identificam na adoção de medidas coercitivas de caráter provisório, já que não se exige julgamento definitivo para que sejam aplicadas.

O Japão foi arrolado entre os países que mais chamaram a atenção de Vittorio Denti.

Surpreendeu-se com a fórmula jamais ao julgamento ${ }^{100}$, traduzida na reprovação social do comportamento do demandante que procura os meios estatais para solucionar um conflito ${ }^{101}$. A decisão judicial, mesmo uma simples condenação a perdas e danos, representa uma declaração de culpa social emitida pela vox dei. Moralmente é mais importante e satisfatório o gesto de pedir perdão e de se sacrificar perante a vítima do ato ilícito, tanto que não é raro os tribunais japoneses ordenarem ao demandado a remessa de uma carta de desculpas ao demandante ou a publicação de uma nota de escusas nos jornais.

Vale apenas o registro da presença do Japão no mencionado encontro, já que as acentuadas diferenças culturais entre ele os demais países participantes, em especial o Brasil, não estimulam comparações de seus provimentos judiciais.

Com sistemas jurídicos bem semelhantes ao francês, a jurisdição dos référés ${ }^{102}$ belga e luxemburguês é a competente para adotar medidas de natureza urgente e provisória.

Georges De Leval, professor da Faculdade de Direito de Liège considera que a eficácia das decisões judiciais se destaca na execução provisória e na jurisdição do référé, cujos pressupostos são a urgência e a provisoriedade.

\footnotetext{
${ }^{100}$ Segundo o Professor Ichiro Kitamura, autor do relatório japonês, $98 \%$ dos conflitos no Japão são resolvidos extrajudicialmente, ob. cit., p. 133/157.

${ }^{101}$ Conta o relatório japonês que um menino morreu ao se afogar num lago próximo de casa, quando estava sob a vigilância de vizinhos. A revolta da opinião pública contra a demanda movida pelos pais chegou a ponto de constrangê-los a desistir da ação indenizatória, mesmo com a vitória em primeiro grau de jurisdição.

${ }_{102} \mathrm{O}$ dicionário Larousse define o référé como o procedimento de urgência pelo qual o juiz regula provisoriamente um litígio ou a própria decisão emitida nesse procedimento.
} 
O primeiro pressuposto é aferido em função da longa espera causada pela natural lentidão da jurisdição competente para apreciar o mérito da demanda e o dano advindo ao demandante se não houvesse a possibilidade de se adotar uma solução provisória. Mas a demora da decisão sobre o mérito deve ameaçar um interesse legítimo e, no caso de uma impugnação fundada, essa ameaça deve ser definida com a comparação entre os prejuízos ao demandante com a manutenção do statu quo e os do demandado com a proibição da prática de determinado ato. Há um largo poder de apreciação a ponto de a mesma situação concreta ser solucionada de modos absolutamente distintos ${ }^{103}$.

Já a urgência é uma noção fluida. Tem contato com situações conexas como celeridade, extrema urgência, perigo de dano, prejuízo. É antes de tudo uma noção funcional que se define não de maneira abstrata, mas em função do resultado que ela busca atender.

A jurisdição dos référés deve examinar o caso concreto com a máxima cautela $^{104}$, ou seja, se há de fato um caráter urgente para a medida e se os imperativos dessa urgência - que se mostram em quase todas as demandas - não podem, por outro lado, ser solucionados na própria jurisdição competente para o mérito e por meio de medidas cautelares. Importa que o référé seja reservado às hipóteses em que se exprime uma necessidade real de soluções imediatas. Para apreciar a urgência, o juiz do référé, tanto de primeiro como de segundo grau, não leva em consideração a data do ajuizamento da demanda ou da primeira decisão, mas sim a situação existente no momento em que irá decidir.

A provisoriedade se divide em duas regras: a primeira, de incompetência absoluta do juiz do référé para apreciar o mérito do litígio; a segunda, de que as decisões do juiz do référé não têm a autoridade da coisa julgada perante o juiz do mérito. A questão da incompetência tem sido mitigada pela jurisprudência que, ao interpretar o art. 1.039 do Código judiciário belga ${ }^{105}$, conclui que o juiz do référé não está impedido de examinar o direito dos litigantes, desde que não ordene medidas

\footnotetext{
${ }^{103}$ Menciona o professor belga que um juiz de référé de Liège impediu o empregador de pagar o empregado por meio de cheque, forma de pagamento imposta de modo unilateral pelo patrão, sob pena de astreinte de 1.000 francos por dia. Mas ao apreciar o mesmo caso, o Tribunal do Trabalho de Charleroi entendeu que o trabalhador aceitara tacitamente o novo modo de remuneração e, portanto, não haviam inconvenientes sérios ao empregado que consubstanciassem urgência.

${ }_{104}$ Avec la plus grande circonspection (L'effectivitée des decisions de justice, p. 50).

105 "Les ordonnances sur référé ne portent préjudice au principal. Elles sont exécutoires par provision, nonobstant opposition ou appel et sans caution, si le juge n'a pas ordonné qu'il en serait fourni une".
} 
capazes de acarretar um prejuízo definitivo e irreparável. A vedação do art. 1.039 não proíbe medidas conservatórias se a aparência do direito é suficiente.

A escolha da medida é feita pelo grau de evidência das pretensões das partes e o provimento não é declaratório nem constitutivo de direito, pois sob o aspecto jurídico se destina exclusivamente a organizar as situações de ameaça em função da aparência jurídica.

O référé tem efeitos bastante práticos e, com freqüência, muitas demandas são solucionadas por meio de transação depois da emissão de provimentos dessa natureza. Comporta medidas de instrução (p. ex. produção antecipada de prova), assim como medidas tomadas depois da contestação do demandado e as injonctions ${ }^{106}$.

Por meio das injonctions de não fazer, por exemplo, os juízes do référé ordenaram a evacuação de ocupantes ilegais de uma fábrica e impediram que o alienante de um fundo de comércio se instalasse em condições de criar concorrência desleal. Injonctions da mesma natureza foram impostas ao Ministro da Educação que, a despeito da regulamentação legal, criou condições para a matrícula de alunos na rede de ensino. Também foram emitidas injonctions contra a Administração ao ameaçar a suspensão ou a interrupção de um serviço público.

Reconhecido um direito e havendo urgência, o juiz do référé pode, sob pena de astreinte, compelir o demandado a realizar a prestação determinada ou mesmo autorizar a parte contrária a cumprir a medida especificada. Nas injonctions de fazer, os juízes já determinaram, por exemplo, a retificação de registro público incorreto, a entrega de documentos, o cumprimento de contrato de empreitada mediante a remessa do material de construção sob pena de astreinte ${ }^{107}$.

Marc Elvinger assinala que a jurisprudência luxemburguesa faz da reparação e da execução in natura o princípio básico nas obrigações de fazer. Não obstante, em algumas obrigações de fazer se torna impossível a tutela específica, razão pela qual se resolverá em perdas e danos conforme o art. 1.142 do Código Civil francês ${ }^{108}$, o qual não poderá ser invocado pelo obrigado se houver uma decisão judicial que determine um fazer ou não fazer. Parte-se do pressuposto de que se há determinação para um fazer ou não fazer, o juiz considerou que a execução específica é compatível com a liberdade

\footnotetext{
${ }^{106}$ A injonction é definida pelo dicionário Larousse como uma ordem formal.

${ }^{107}$ A provisioriedade não veda ao juiz do référé o exame do direito das partes e a emissão de uma condenação provisória ao pagamento de uma soma em dinheiro. Trata-se do référé-provision, que exige a urgência e um crédito incontroverso.

${ }^{108}$ Segundo o qual o descumprimento das obrigações de fazer ou de não fazer se resolve em perdas e danos e juros.
} 
individual do obrigado e a condenação ao pagamento de uma soma em dinheiro não é a adequada ao caso concreto.

Há uma ligação estreita entre a execução in natura e as medidas de coerção postas ao dispor do juiz, entre elas as astreintes. Mas ao contrário da obrigação de pagar, que legitima o uso da força (penhora, arresto, busca e apreensão), na obrigação de fazer o credor não tem o direito de compelir fisicamente o devedor. É por essa razão que o juiz deve prever uma solução subsidiária ou um meio de pressão se houver resistência do devedor em fazer ou não fazer algo. Por óbvio, essa solução subsidiária não é evidentemente a condenação ao ressarcimento de perdas e danos, sob o risco de privar o credor de seu direito à tutela específica ${ }^{109}$.

São três as categorias dos meios postos à disposição do credor para assegurar a efetividade da decisão: recurso à força policial, sub-rogação e meios de pressão.

Descartado o emprego das astreintes, o uso da força policial foi utilizado numa ordem de evacuação de um imóvel, bem como em questões de guarda e visita dos filhos. A sub-rogação subjetiva foi autorizada na abertura de servidão de passagem e na reparação de prédio danificado.

Meio indireto de execução, a astreinte vigora em Luxemburgo desde $1^{\circ}$ de outubro de 1978 por força da Convenção BENELUX e de lei uniforme sobre esse instrumento. Conforme o art. 2059 do Código Civil francês, a astreinte não será imposta em caso de condenação ao pagamento de soma em dinheiro. É uma pena civil, imposta a pedido da parte e devida ao particular, não se confundindo com as perdas e danos. É cabível nas obrigações de fazer, não fazer e dar, e pode ser aplicada tanto pelos juízes do référé como pelos juízes do mérito.

Não há em Luxemburgo o instituto do contempt of court, porém ocorrem situações em que o descumprimento da ordem judicial é sancionado pela lei penal (p. ex., concorrência desleal, abandono material do menor).

Fruto de sua própria história, a Louisiana ostenta características singulares quando comparada com os demais estados que compõem os Estados Unidos da América. É uma jurisdição mista, regida por um Código Civil de tradições românicas e pelo intercâmbio de influências e de instituições da civil e da common law.

\footnotetext{
${ }^{109} \mathrm{O}$ autor desconhece na jurisprudência de Luxemburgo algum precedente em que o devedor tenha sido condenado a perdas e danos por frustrar uma obrigação de fazer ou de não fazer (L'effectivité des decisions de justice, p. 205).
} 
No direito processual, a influência mais acentuada é a anglo-americana, pois nunca se adotou na Louisiana um código de processo de tradição francesa que pudesse concorrer com o direito processual americano. Além disso, logo nos primeiros anos de existência desse estado norte-americano, já se percebia que o temperamento dos juízes era muito mais afinado com os institutos anglo-americanos do que com os franceses.

O sistema federativo norte-americano admite que o direito substancial de algum estado seja diferente das regras nacionais, mas não aceita que o direito processual dos estados se afaste das normas nacionais. Assim, poderá o demandante obter uma decisão favorável num estado que contrarie o direito material do estado em que a ordem judicial será cumprida. Para o cumprimento da decisão, a Corte encarregada da execução apenas verificará se houve o respeito das regras processuais, em especial a citação válida e a ausência de fraude.

O Código Civil da Louisiana distingue as obrigações de fazer, de não fazer e dar, seguindo as categorias medievais. A obrigação de dar (ou entregar), de um modo geral não apresenta dificuldades práticas na execução, pois bastará uma ordem (busca e apreensão ou imissão na posse) para a satisfação do credor.

Nas obrigações de pagar, o registro da demanda na circunscrição em que o devedor tem os seus bens é uma medida simples para forçá-lo ao adimplemento. Ainda que não tenha bens no momento do registro, não poderá vender ou onerar aqueles adquiridos posteriormente sem antes liquidar a dívida. Tal registro deve ser feito a cada dez anos para evitar a prescrição. Se o credor não obtém a satisfação do crédito espontaneamente, pode pedir ao sheriff local a apreensão e a adjudicação dos bens do devedor para cobrir a dívida, além das custas e despesas processuais. Também há a possibilidade de buscas e bloqueios de bens e de direitos.

Os juízes da Louisiana, assim como os juízes norte-americanos, preferem não restringir a liberdade individual do devedor, ordenando-lhe que faça algo contra a sua vontade, sob pena de prisão. A sub-rogação subjetiva tem sido mais adotada, inclusive para evitar que o obrigado, maliciosamente, pratique o comportamento determinado de forma defeituosa. Caso seja possível atribuir a outrem a atividade, a Corte o fará, impondo ao obrigado o pagamento das despesas decorrentes. Vale lembrar que o cumprimento da obrigação poderá exigir uma supervisão judicial contínua, bem como a formulação de novos pedidos ao juiz para que aprecie e dirima problemas não previstos e provocados por circunstâncias supervenientes. 
Mas Shael Herman e Alan Ezkovich assinalam ser histórica a preferência pela via das perdas e danos. No precedente inglês "Bromage vs. Genning", o demandado se comprometera a assinar um contrato de locação e não o fizera. Lorde Coke lhe conferiu a opção de assinar o contrato ou pagar perdas e danos. Séculos depois, o juiz norteamericano O. W. Holmes sustentou a mesma tese no artigo "The Path of the Law", afirmando que a obrigação de cumprir um contrato significa que o inadimplemento resultará exclusivamente nas perdas e danos.

Essa preferência também reflete a divisão entre os sistemas da common law e da equity, cuja fusão foi tentada com bastante empenho durante o Século XIX. A Louisiana nunca conheceu essa distinção entre os dois sistemas. As diferenças sobrevivem apenas no espírito da maioria dos juízes e advogados. Atualmente nos Estados Unidos quase não mais existem Cortes exclusivas de equity, embora os provimentos judiciais desses dois sistemas apresentem diferenças.

Enquanto os provimentos da common law se direcionam ao patrimônio do obrigado (in rem), os da equity, consubstanciados em injunctions de fazer ou não fazer, incidem sobre a pessoa do devedor. Ambas as modalidades são admitidas, ao passo que o direito da Louisiana estimula a sub-rogação subjetiva para as obrigações de fazer ou não fazer, permitindo que a Corte requisite ao xeriff ou a outra pessoa a realização ou a abstenção do ato à custa do devedor.

Entre os provimentos de fazer ou não fazer, destaca-se o writ of possession, ordem cumprida pelo xerife e que apreende os bens móveis do devedor e os entrega ao credor e, tratando-se de imóveis, a ordem é de evacuação, inclusive com o uso da força. Não localizada a coisa a ser entregue, o lesado poderá obter um provimento de distringas, na verdade um writ para a apreensão de outros bens do devedor, uma sentença por desacato ao juiz ou uma sentença indenizatória.

Apesar do poder que têm, as Cortes da Louisiana raramente optam pelo procedimento do contempt of court ${ }^{110}$, que inclui tanto o descumprimento da ordem judicial, como também o desrespeito ou a falta de decoro durante o procedimento. Trata-se de modo indireto e bastante severo de execução indireta. Pode resultar em prisão por tempo ilimitado. Embora a sua natureza seja praticamente criminal, as garantias de que dispõe um acusado no processo crime não são obrigatórias, cabendo ao habeas corpus corrigir ofensas ao direito de defesa.

\footnotetext{
${ }^{110}$ Segundo os autores, as Cortes preferem aplicar multas depois de sem êxito advertir o obrigado para o cumprimento da ordem (L'effectivité des décisions de justice., p. 188).
} 


\section{Das medidas para a efetivação dos provimentos.}

\subsection{Hipóteses de incidência.}

A primazia da tutela específica sobre a indenização nas obrigações de fazer ou não fazer relacionadas aos direitos coletivos não decorre apenas da lei ( $\operatorname{art.~} 84, \S 1^{\circ}$, do $\mathrm{CDC}$ ), mas também da natureza e das peculiaridades desses direitos. O pagamento de soma em dinheiro pela poluição do ar, por exemplo, não trará nenhum benefício direto à coletividade. A indenização pela venda de produto deteriorado não será tão proveitosa à sociedade quanto à sua imediata retirada do mercado ${ }^{111}$.

Mas a determinação judicial para que alguém faça ou deixe de fazer algo pode não ser cumprida pelo devedor, seja por circunstâncias alheias à sua vontade, seja pela intenção deliberada de desobedecer. Nestas situações, caberá ao juiz emitir decisões, nem sempre previstas na legislação, que tornem realidade o fazer ou não fazer e, para tanto, agirá com certa flexibilidade e sem uma rígida vinculação a modelos previamente traçados pelo legislador, o que remete a breves reflexões sobre o poder discricionário do juiz nesse campo, qual seja, o do inadimplemento das obrigações de fazer ou não fazer impostas por decisão judicial.

Antes do exame da discricionariedade judicial, urge registrar que a classificação de Giuseppe Chiovenda para os meios executivos ${ }^{112}$, em razão de sua simplicidade e clareza foi aqui adotada para as medidas de efetivação dos provimentos.

\subsection{Discricionariedade ou criatividade judicial.}

O termo discricionariedade costuma evocar de imediato a idéia de arbítrio, de abuso ou de desvio de poder. Para muitos processualistas brasileiros ${ }^{113}$, a

${ }^{111}$ Para Luiz Guilherme Marinoni, "não há dúvida de que a tutela específica protege de modo mais adequado o direito material. A tutela dirigida a evitar o ilícito é, evidentemente, muito mais importante do que a tutela ressarcitória. No caso de dano, principalmente de conteúdo não patrimonial, o ressarcimento da forma específica é o único remédio que permite que o dano não seja monetizado e que o direito, assim, encontre uma forma efetiva de reparação" (Tutela específica, p. 70).

${ }_{112}$ Para o citado autor, os meios executivos podem ser divididos em meios de coação e meios de subrogação. Os primeiros "tendem a fazer conseguir para o credor o bem a que tem direito com participação do obrigado, e, pois se destinam a influir sobre a vontade do obrigado para que se determine a prestar o que deve". Os meios de sub-rogação "objetivam, por sua conta, fazer conseguir para o credor o bem a que tem direito, independentemente de participação e, portanto, da vontade do obrigado" (Instituições...,vol. 1, p. 349/350). 
discricionariedade judicial não existe, pois no exercício da função jurisdicional, o juiz aplica a regra jurídica abstratamente prevista para a solução daquele caso concreto e, ao contrário do administrador, não age à luz da conveniência e da oportunidade inerentes ao mérito do ato administrativo discricionário. Em outras palavras, ao juiz não se atribuiria liberdade de escolha de uma entre várias opções possíveis para a emissão de determinado provimento ${ }^{114}$.

Porém é incompleta a noção de que o mérito do ato administrativo se assenta apenas na conveniência e na oportunidade. Há décadas, M. Seabra Fagundes ressaltava que o mérito é o próprio sentido do ato em função das normas da boa administração, que atende ao interesse público e compreende outros aspectos referentes ao "acerto, à justiça, utilidade, eqüidade, razoabilidade, moralidade, etc" $" 115$.

Num conceito mais atual, a discricionariedade "é a margem de liberdade que remanesça ao administrador para eleger, segundo critérios consistentes de razoabilidade, um, dentre pelo menos dois comportamentos cabíveis, perante cada caso concreto, a fim de cumprir o dever de adotar a solução mais adequada à satisfação da finalidade legal, quando, por força da fluidez das expressões da lei ou da liberdade conferida no mandamento, dela não se possa extrair objetivamente, uma solução unívoca para a situação vertente" ${ }^{, 116}$.

Tal conceito adere com precisão ao disposto no art. 84 do Código de Defesa do Consumidor, já que ao juiz se permite a adoção de "medidas necessárias" para a efetividade da tutela específica ou que "assegurem o resultado prático equivalente ao adimplemento". Há, portanto, discricionariedade, mas que "deve ser bem entendida. Não se trata de adoção arbitrária de qualquer medida, e sim apenas de medidas adequadas e necessárias (eis o parâmetro legal) à tutela específica da obrigação ou à obtenção do resultado equivalente" ${ }^{, 117}$.

\footnotetext{
${ }^{113}$ Entre eles, Arruda Alvim que, a propósito da antecipação dos efeitos da tutela e à luz dos conceitos extraídos do Direito Administrativo, considera "infeliz" dizer que o ato discricionário enseja soluções diversas (Manual..., vol. 2, p. 385/387).

${ }^{114}$ Em sentido bastante contrário, Roberto Marengo se refere a um dever discricionário do juiz que, em regra, não se manifesta nos provimentos de mérito do processo civil, mas se evidencia naqueles relacionados ao procedimento. Exemplo citado pelo autor é o art. 700 do Código de Processo Civil italiano, que trata dos provimentos de urgência e nos quais a discricionariedade do juiz é marcante e sem que haja correspondência exata entre o pedido e o próprio provimento de natureza urgente (Note in tema di discrezionalità del giudice civile, p. 165/168).

115 O controle dos atos administrativos..., p. 167/168.

116 Celso Antônio Bandeira de Mello. Discricionariedade e controle jurisdicional, p. 48.

${ }^{117}$ Kazuo Watanabe. Tutela antecipatória e tutela específica nas obrigações de fazer e não fazer, p. 45.
} 
Em suma, é preciso deixar de lado o debate de caráter acima de tudo semântico acerca da discricionariedade judicial ${ }^{118}$ e voltar os olhos para o plano da efetividade das decisões judiciais.

A emissão de uma ordem para que alguém faça ou deixe de fazer algo é em termos simples o resultado do confronto de um fato estaticamente considerado com a norma jurídica específica. Mas a solução a ser dada perante o descumprimento voluntário ou involuntário dessa ordem não costuma ser fácil. A lei não prevê toda a dinâmica nem a mutação das situações de inadimplemento, de modo que a postura do julgador diante disso será muito mais a de um administrador ou executor da decisão judicial. A atividade de dizer o direito já fora realizada. Há um comando a ser posto em prática e sob uma conjuntura muitas vezes diferente e a exigir providências criativas do julgador, que não as encontrará nos arquétipos dos textos legais.

Cândido Rangel Dinamarco bem ilustra a diversidade de provimentos judiciais sem expressa previsão legal diante do inadimplemento do obrigado: uma casa noturna é condenada a não produzir ruídos acima de tantos decibéis. Intimada, não cumpre o preceito. O juiz determina que o oficial de justiça compareça ao local e abaixe o volume dos equipamentos. Porém, logo em seguida, o estabelecimento aumenta o volume e continua a incomodar a vizinhança. Novo provimento é emitido, desta vez para que o oficial de justiça faça a busca e a apreensão do equipamento. Mas a casa noturna adquire outros aparelhos, o que leva o juiz a mandar lacrar o estabelecimento. A medida é drástica, mas assegura um resultado prático equivalente ao do adimplemento ${ }^{119}$.

Em razão das características dos interesses coletivos, em especial a sua mutação no tempo e no espaço e a intensa conflituosidade, a postura do magistrado na condução do processo e, em conseqüência, na emissão de provimentos, poderá exigir bastante criatividade ${ }^{120}$ a fim de que o resultado prático da tutela jurisdicional seja assegurado. Essa criatividade, por sua vez, representa uma ruptura com o papel

\footnotetext{
118 Para Elio Fazzalari, a discricionariedade do juiz "diz respeito a alguns momentos da existência processual". Seu âmbito é exíguo se cotejado à administração, visto que o "juiz atua em uma estrutura processual (isto é, com contraditório) e que grande parte da atividade processual é desenvolvida pelas partes" (Instituições de direito processual, p. 419).

${ }_{119}$ A reforma da reforma, p. 227/228.

120 "Que o juiz não se limita a utilizar normas pré-fabricadas, mas desempenha também aí um função criadora, é coisa de que ninguém mais duvida. O juiz simples boca da lei, sonhado por antiga doutrina, se alguma vez existiu, é defunto de longa data sepultado. Há limites, contudo, para semelhante criação. $\mathrm{O}$ juiz cria nos interstícios da rede normativa; não se lhe permite sobrepor a ela sua fantasia, sorvida que seja nas fontes mais puras e alimentada pelas mais santas intenções. Falece ao juiz legitimação política para irrogar-se com amplitude o papel de legislador" (José Carlos Barbosa Moreira. O juiz e a cultura da transgressão, "in" Temas de direito processual, $7^{\mathrm{a}}$ série, p. 259/260).
} 
tradicional do julgador e o convida de modo constante à percepção de suas novas e importantes funções, que não se limitam a dizer o direito, mas também efetivá-lo à luz de um contexto social, político e econômico em constante alteração ${ }^{121}$.

\subsection{Limites.}

Sabido que o poder de criação do juiz não é absoluto, pois até mesmo os atos administrativos discricionários exigem a observância do princípio da legalidade, além de fundamentada por imposição do art. 93, IX, da Constituição Federal e sujeita ao controle recursal como todas as decisões judiciais que podem lesar uma das partes, a medida para a efetivação do comando de fazer ou não fazer é ato de extrema prudência e responsabilidade do julgador.

$\mathrm{Na}$ seara das demandas coletivas, o bom senso e a serenidade devem ser redobrados. O dinamismo e a mutação dos interesses em jogo, bem como a repercussão social e econômica das decisões nelas prolatadas são fatores relevantes à reflexão do juiz para a elaboração da medida concreta.

Uma vez que a norma aberta do art. 84 do $\mathrm{CDC}^{122}$ não estipula parâmetros para a seleção do rol exemplificativo de medidas é preciso buscar no ordenamento jurídico os critérios que devem nortear e limitar a atividade judicial diante das situações de inadimplemento do obrigado.

Evidente que as medidas ora tratadas não serão aplicadas na hipótese de descumprimento de ônus processual, mas sim para o inadimplemento de dever reconhecido no processo e destinado a satisfazer o direito do adversário. Recorde-se com as lições de Francesco Carnelutti que se fala em ônus "quando o exercício de uma faculdade aparece como condição para obter uma determinada vantagem; por isso o

\footnotetext{
${ }^{121}$ A propósito do poder geral de cautela do juiz e das medidas atípicas, Galeno Lacerda sustenta que não há criação do direito material em abstrato, porém "as providências variadas e imprevisíveis, impostas pela força dos fatos, fazem com que os decretos do magistrado assumam o caráter de normas e imperativos concretos de conduta, que significam, na verdade, autêntica obra de descoberta e criação singular do direito, emanada do fato, colada ao fato, nascida para o fato. Nesta perspectiva, rasga-se a imagem tradicional do juiz preso e manietado do sistema continental, e dá-se ao juiz moderno dos países codificados o mesmo horizonte criador e novo do pretor romano e dos magistrados anglo-americanos" (Comentários..., p. 114/115).

${ }^{122}$ É praticamente unânime o entendimento doutrinário de que ao aplicar as medidas de sub-rogação, estímulo ou coerção, ainda que não requeridas pela parte, o juiz não viola o princípio da correlação entre o pedido e a sentença, até porque com o emprego daquelas visa a assegurar o resultado prático equivalente, isto é, o próprio fazer ou o não fazer determinado pelo comando da sentença (ou da decisão).
} 
ônus é uma faculdade cujo exercício é necessário para a obtenção de um interesse. Obrigação e ônus têm em comum o elemento formal consistente no vínculo da vontade; mas diferem no elemento substancial, porque quando há obrigação, o vínculo se impõe para a tutela de um interesse alheio, e para a tutela de um interesse próprio, quando se tratar do ônus" ${ }^{\prime 123}$. Logo, não se cogitará na aplicação das medidas de coerção ou de subrogação, por exemplo, se a parte não comparece para o depoimento pessoal, não apresenta defesa no prazo legal, não deposita salários periciais, não oferta quesitos para a perícia etc.

Numa segunda reflexão seria bastante intuitivo cogitar que o principal limite à criação de uma medida judicial residiria nos direitos e garantias fundamentais da Constituição Federal ${ }^{124}$, de modo que ao juiz seria vedada a criação de um provimento que os afrontasse. Não obstante, o próprio art. $5^{\circ}$, LIV, da Magna Carta estatui ( $a$ contrario sensu) que o indivíduo poderá ser privado da liberdade ou dos seus bens mediante o devido processo legal. Logo, assegurado o procedimento em contraditório, observadas a isonomia dos litigantes, a ampla defesa, a imparcialidade, a competência do juiz e a fundamentação da decisão, entre outros corolários do processo justo, a liberdade e o patrimônio do destinatário do provimento judicial podem ser subtraídos ${ }^{125}$.

Ocorre que a constitucionalização de inúmeros direitos trouxe maiores dificuldades ao julgador para a solução das controvérsias, pois não raro as partes invocam dispositivos constitucionais para a tutela de seus interesses em litígio e tal antagonismo tem de ser superado com a manutenção da coerência do ordenamento jurídico, ou seja, sem eliminar por completo um princípio ou uma norma da mesma hierarquia $^{126}$.

Com o apoio de farta doutrina, Ada Pellegrini Grinover invoca o princípio da proporcionalidade para solucionar a colisão de princípios constitucionais e, sem dúvida,

\footnotetext{
${ }^{123}$ Sistema de direito processual civil, vol. I, p. 119.

124 José Afonso da Silva invoca lição de Ruy Barbosa para diferenciar os direitos das garantias constitucionais: as disposições meramente declaratórias tratam dos direitos, enquanto que a as disposições assecuratórias, "que são as que, em defesa dos direitos, limitam o poder", instituem as garantias. Ocorre que "não raro o direito fundamental se exprime pela norma de garantia; está subentendido nesta" (Curso de direito constitucional positivo, p. 355).

${ }^{125}$ De fato, os direitos e garantias fundamentais "não são ilimitados, uma vez que encontram seus limites nos demais direitos igualmente consagrados pela Carta Magna (princípio da relatividade ou convivência das liberdades públicas)" (Alexandre de Moraes. Direito constitucional, p. 59).

${ }^{126}$ Nas antinomias comuns, a solução desse impasse se dá pelos critérios da cronologia, hierarquia e especialidade. Mas os três são insuficientes, já que geralmente os conflitos ocorrem entre normas contemporâneas, do mesmo nível e de caráter geral.
} 
esse será o principal limitador da atividade judicial, caso a caso, no que toca à escolha da medida para a efetivação dos provimentos de fazer ou não fazer.

Entendida como o "justo equilíbrio entre os meios empregados e os fins a serem alcançados”, a proporcionalidade leva em consideração os seguintes dados: “(i) adequação, ou seja, a aptidão da medida para atingir os objetivos pretendidos; (ii) necessidade, como exigência de limitar um direito para proteger outro, igualmente relevante; (iii) proporcionalidade estrita, como ponderação da relação existente entre os meios e os fins, ou seja, entre a restrição imposta (que não deve aniquilar o direito) e a vantagem conseguida, o que importa na (iv) não-excessividade"127.

Em síntese, a medida deve ser necessária e adequada ${ }^{128}$, sem acarretar ao destinatário uma lesão pessoal ou material excessiva e desproporcional ao direito que violou. É preciso equacionar os valores jurídicos em jogo com racionalidade e coerência entre os meios empregados e os fins almejados.

Luiz Guilherme Marinoni, por seu turno, conclui que a escolha da medida é casuística e não há nenhuma "precisa e exata tabela para o uso das medidas de execução". A atuação do juiz será guiada pelo princípio da necessidade, que se desdobra nos princípios do meio idôneo e da menor restrição possível. Diante da tensão entre o direito à efetividade da tutela jurisdicional e os direitos do destinatário do provimento, caberá ao juiz empregar a técnica executiva mais adequada ao caso concreto e com fundamentação suficiente. Lembra o mencionado autor que "a necessidade de o juiz explicar os seus motivos de maneira bastante precisa, advém do fato de hoje não mais vigora o princípio da tipicidade dos meios executivos, mas sim o da concentração dos poderes de execução do juiz, uma vez que a ele foi outorgada ampla latitude de poder destinada à determinação da modalidade executiva adequada ao caso concreto. Na realidade, a necessidade de justificação caminha de mãos dadas com este poder que foi conferido ao juiz" ${ }^{129}$.

Em arremate, o magistrado extrapolará os limites da criação de medidas para a efetivação dos provimentos sempre que a sua decisão não contiver motivação suficiente ou for desproporcional à luz do caso concreto.

\footnotetext{
${ }^{127}$ Princípio da proporcionalidade..., "in” O processo: estudos e pareceres, p. 8/9.

${ }^{128}$ Ao tratar da adequação nos aspecto subjetivo, objetivo e teológico, Galeno Lacerda faz interessante analogia entre os instrumentos processuais e o cinzel de Aleijadinho, os quais pressupõem um sujeito, "um objeto sobre o qual, mediante aquele, atua o agir, e uma finalidade que condiciona a ação" (Comentários..., p. 25).

${ }^{129}$ Tutela inibitória, p. 239/241.
} 


\subsection{Medidas sub-rogatórias.}

Descumprido o comando judicial de fazer ou não fazer fungível, seja por ato voluntário do devedor seja por fatores alheios à sua vontade, poderá o juiz, sempre atento aos limites acima expostos, adotar medidas de sub-rogação objetiva ou subjetiva.

No primeiro caso (sub-rogação objetiva), a conversão mais comum é a que impõe ao devedor o pagamento de soma em dinheiro em vez de obrigá-lo a fazer ou deixar de fazer algo. Não se inclui nos propósitos deste trabalho examinar aspectos da execução por quantia certa, justamente porque nas demandas coletivas a conversão da obrigação de fazer ou não fazer em perdas e danos é a última das alternativas escolhidas pelo legislador para a efetivação da tutela jurisdicional.

Interessa a tutela específica e, em conseqüência, as técnicas processuais para que os resultados práticos equivalentes da obrigação inadimplida sejam alcançados, ou seja, para impedir, cessar ou remover o ilícito.

Kazuo Watanabe exemplifica uma eficaz medida sub-rogatória objetiva a partir do dever atribuído ao destinatário do provimento judicial de não poluir. Descumprida a ordem, "poderá a obrigação de não fazer ser sub-rogada em obrigação de fazer (v.g. colocação de filtro, construção de um sistema de tratamento de efluente etc.), e descumprida esta obrigação sub-rogada de fazer poderá ela ser novamente convertida, desta feita em outra de não fazer, como a de cessar a atividade nociva. A execução desta última obrigação pode ser alcançada coativamente, inclusive através de atos executivos determinados pelo juiz e atuados por seus auxiliares, inclusive com a requisição, se necessário, de força policial ( $\$ 5^{\circ}$ do art. 461). São meios sub-rogatórios que o juiz deverá adotar enquanto for possível a tutela específica ou a obtenção do resultado prático equivalente, em cumprimento ao mandamento contido no $\S 1^{\circ}$ do art. $461^{\prime 130}$.

Luiz Guilherme Marinoni, por sua vez, considera que a sub-rogação "é medida de menor efetividade diante da multa e da coerção direta, e assim somente deve ser utilizada nos casos em que uma das duas primeiras for absolutamente inviável"131. Vale lembrar que o referido autor entende que as medidas sub-rogatórias são diversas das

\footnotetext{
${ }^{130}$ Tutela antecipatória e tutela específica..., p. 44/45.

${ }^{131}$ Tutela inibitória, p. 232.
} 
providências de coerção direta sobre o devedor, arrolando entre estas a nomeação de um auxiliar do juízo para o adimplemento da obrigação ${ }^{132}$.

Ocorre que somente as peculiaridades da situação concreta é que poderão propiciar ao juiz elementos de convicção para elaborar a medida mais adequada à tutela específica da obrigação. Portanto, não se mostra sustentável sob o aspecto jurídico e prático colocar as medidas de sub-rogação como a última alternativa para a efetividade da tutela coletiva.

Haverá a sub-rogação subjetiva com a substituição da conduta do obrigado pela atividade judicial. Alerta Araken de Assis que "desaparecida a vinculação da pessoa à dívida, paulatinamente aproximados responsabilidade e objeto da prestação, a técnica executiva sub-rogatória da conduta do titular do dever jurídico, pela atividade jurisdicional, assumiu papel de grande envergadura. Exceção feita àqueles deveres em que o cumprimento no tempo, no modo e no lugar devidos desperta tensão peculiar isto é, no facere infungível -, revela-se factível, contra e independentemente da vontade do executado, entregar ao exeqüente o corpus e o genus almejados"133. Lembra, ainda, que as diferenças desses meios sub-rogatórios de execução direta residem apenas no modo de penetração na esfera patrimonial do devedor e arrola as técnicas previstas para a expropriação pecuniária (adjudicação, alienação por iniciativa particular, alienação em hasta pública e usufruto forçado) nas quais a participação do executado é abstraída.

Além dos casos do administrador judicial da massa falida e daquele encarregado de realizar a penhora do faturamento da pessoa jurídica devedora, o ordenamento jurídico vigente contempla outras hipóteses de sub-rogação subjetiva mediante a atuação de auxiliar do juízo ${ }^{134}$.

Uma delas está contida na Lei $n^{\circ} 8.884 / 94$, que trata da prevenção e da repressão às infrações contra a ordem econômica e atribui ao juiz o poder de nomear

\footnotetext{
${ }^{132}$ Assim escreve o referido autor: "quando a atuação executiva não implica na prática de fazer que já deveria ter sido observado, e assim não pode ser dita substitutiva do fazer, há medida de coerção direta, e não medida de sub-rogação. No caso em que a atuação executiva não presta o fazer inadimplido, mas apenas é necessária para garantir, independentemente da vontade do réu, a efetividade da tutela jurisdicional, a medida é de coerção direta" (id., ibid.). Com a mais absoluta humildade intelectual, não vemos sentido prático e não alcançamos a utilidade em sustentar que a nomeação de um auxiliar do juízo, que cumprirá o fazer ou o não fazer, é tão somente medida de coerção direta e não sub-rogatória. Ora, a sub-rogação é em termos simples a substituição, a transferência da obrigação ou da pessoa do obrigado e, ainda que essa providência coaja o devedor, não parece perder o caráter de sub-rogação.

${ }^{133}$ Manual da execução, p. 136. Exemplos clássicos do fazer infungível são aqueles do pintor de renome que se recusa a pintar o retrato do credor e o da cantora lírica que não se apresenta no concerto.
} 
interventor na empresa infratora pelo prazo de 180 dias a fim de que seja cumprida a tutela específica de fazer ou não fazer.

Caberá a este auxiliar do juízo apresentar relatório mensal de suas atividades, comunicar eventuais irregularidades praticadas pelos responsáveis pela empresa e, enfim, praticar ou determinar a prática dos atos necessários ao cumprimento do comando judicial (art. 75). Embaraçada a atuação do interventor, o ato poderá caracterizar os crimes de resistência, desobediência ou desacato, bem como o afastamento dos responsáveis pela administração da empresa, que serão substituídos na forma do contrato social e, ao persistir a recusa na colaboração do interventor, o juiz determinará que este assuma a administração integral da empresa (art. 74).

Apesar de drástica, a intervenção judicial poderá significar em determinados casos o único meio eficaz para assegurar a tutela específica da obrigação. Conquanto não prevista expressamente para a defesa de outros direitos de natureza coletiva, a aplicação analógica das regras da Lei Antitruste será de plena utilidade para a observância do provimento judicial ${ }^{135}$.

Um episódio real comprova de modo satisfatório a superioridade dessa medida de sub-rogação sobre as outras técnicas para a efetivação dos provimentos judiciais ${ }^{136}$.

Numa cidade do interior paulista funcionava um abrigo particular para crianças, adolescentes e idosos. Dados colhidos em inquérito civil indicavam as precárias condições de segurança e higiene no local. Além disso, internos de sexos e faixas etárias diferentes ocupavam os mesmos dormitórios em ambiente promíscuo, ao passo que o expressivo número de reclamações trabalhistas de antigos funcionários da instituição colocava em risco as receitas obtidas por meio de doações privadas.

No escopo de dar cumprimento às normas de proteção aos menores e idosos, o Ministério Público ajuizou ação coletiva para obrigar o responsável pela entidade a adotar em prazo razoável as medidas necessárias para adequar o estabelecimento às normas de proteção das crianças, adolescentes e idosos. A liminar foi concedida e o réu, além de não cumpri-la, evadiu-se ${ }^{137}$.

\footnotetext{
${ }^{135}$ Lembra Kazuo Watanabe que "o modelo desta última lei sugere a possibilidade de adoção de medidas assemelhadas àquelas adotadas pelo sistema norte-americano, que prevê as figuras do receiver, master, administrators e committees" (Tutela antecipatória e tutela especifica..., p. 45).

${ }^{136}$ No escopo de preservar a identidade dos envolvidos, alguns fatos, fundamentos e pedidos do processo em questão foram alterados de modo proposital pelo autor deste trabalho, que não acompanhou o feito até o seu arquivamento, mas presenciou a eficácia da medida sub-rogatória adotada pelo juiz.

${ }^{137}$ Patente, assim, a inutilidade de medidas de coerção como as astreintes e a ameaça de prisão por desobediência.
} 
O impasse estava instaurado, pois não havia outro lugar na Comarca para acolher os internos, tampouco era conveniente ou havia sido pleiteada a dissolução da pessoa jurídica que, bem ou (muito) mal, prestara um serviço que a sociedade local não poderia abdicar.

A solução encontrada pelo magistrado foi designar uma junta interventora. Composta por médicos, assistentes sociais, advogados, psicólogos, contadores, engenheiros e voluntários de diferentes formações profissionais, a junta multidisciplinar acompanhou o cotidiano do abrigo e aos poucos foi solucionando as irregularidades verificadas. Os integrantes se reuniam semanalmente e elaboravam relatório pormenorizado de suas atividades ao juízo, solicitando quando necessário a expedição de ofícios e alvarás para a prática de determinados atos perante órgãos públicos e privados.

O êxito da medida sub-rogatória foi absoluto e, por óbvio, não resultou apenas da criatividade judicial, mas preponderantemente da solidariedade dos integrantes da referida junta interventora.

Um entrave de ordem prática para a adoção de medidas sub-rogatórias subjetivas - e não enfrentado no episódio acima narrado em razão do altruísmo daquela comunidade - diz respeito à remuneração do auxiliar do juízo. O art. 19 Código de Processo Civil inviabiliza com freqüência esse tipo de medida e é raro o juiz encontrar profissionais dispostos a trabalhar de graça e ainda arcar com os custos para a execução de suas atribuições ${ }^{138}$.

\subsection{Medidas de coerção e de sanção.}

As medidas de coerção e de sanção podem incidir sobre o patrimônio ou a pessoa do obrigado. Meios para compelir ou estimular o destinatário do provimento a cumpri-lo, “inexistirá razão para que se recorra a esta técnica, quando o credor pode obter por meio indireto a satisfação específica do seu direito" ${ }^{139}$.

De fato, a ameaça de prisão por desobediência à ordem judicial, bem como a imposição de multa diária por descumprimento do preceito nem sempre asseguram o

\footnotetext{
${ }^{138}$ No anteprojeto do Código Brasileiro de Processos Coletivos, o art. 12 trata tanto do ônus da prova como também dos custos com a sua produção. O juiz poderá requisitar a perícia à entidade pública cujo objeto estiver ligado à matéria em debate. Na impossibilidade, ordenará a sua realização a cargo do Fundo de Direitos Difusos e Individuais Homogêneos.

${ }^{139}$ José Carlos Barbosa Moreira. Tendências na execução de sentenças e ordens judiciais, "in" Temas de direito processual, $4^{\mathrm{a}}$ série, p. 237.
} 
resultado prático equivalente ao fazer ou ao não fazer. O ilícito penal é considerado de menor potencial ofensivo e contemplado com todos os benefícios da Lei $n^{0}$ 9.099/95 (suspensão do processo, transação penal etc), enquanto que a multa só surtirá efeitos em face do devedor solvente e com patrimônio apto a ser expropriado.

\subsubsection{Contempt of court.}

Embora o ingresso desse instituto da common law no ordenamento jurídico nacional por intermédio da Lei $\mathrm{n}^{\circ} 10.358 / 2001$ tenha sido aclamado pelos estudiosos, os poucos anos de vigência do novo art. 14 do Código de Processo Civil foram suficientes para demonstrar a sua absoluta inocuidade em nosso sistema.

Em termos simples, contempt of court significa o ato de desprezo ou de desobediência pela Corte. Fruto do dualismo da common law e da equity, divide-se em civil e criminal. O primeiro se destina ao cumprimento da decisão judicial e o segundo a punir o infrator. Ambos podem coexistir, à medida que no contempt civil direto facultase ao juiz determinar a prisão imediata do desobediente até que cumpra o provimento ou justifique a impossibilidade de executá-lo e no civil indireto instaurar-se-á um procedimento incidental para apurar se a parte cometeu ou não o ato atentatório e lhe impor sanção (prisão, multa, perda de direito processual ou seqüestro) caso não cumpra o preceito.

Seguindo a cronologia das propostas apresentadas para a alteração do art. 14 do Código de Processo Civil, Ada Pellegrini Grinover concluiu em magnífico estudo ${ }^{140}$ que o contempt of court brasileiro nasceu morto.

O texto elaborado por comissão presidida pelo Ministro Sálvio de Figueiredo Teixeira e encaminhado ao Ministério da Justiça sofreu alteração e no $\S 2^{\circ}$ do citado artigo estabeleceu a prisão civil de até trinta dias para o destinatário do provimento judicial que, advertido, reiterava a conduta atentatória ao exercício da jurisdição. Com isso, incorporava-se ao direito brasileiro o instituto do contempt of court e se atribuía à multa o caráter coercitivo. Mas o projeto de Lei ${ }^{0} 3.475 / 2000$ suprimiu a prisão civil e a nova redação do parágrafo único conferiu à multa o caráter de sanção, uma vez que a sua exigibilidade depende do "trânsito em julgado da decisão final da causa".

\footnotetext{
${ }^{140}$ Paixão e morte do 'contempt of court' brasileiro, “in” O processo: estudos e pareceres, p. 158/166.
} 
$\mathrm{Na}$ redação final da Lei $\mathrm{n}^{\circ} 10.358 / 2001$, os advogados foram isentados da multa e "assim se liquidou, com outra penada, toda a doutrina e a prática dos tribunais anglo-saxões em torno do contempt of court, cuja longa experiência havia evidenciado que entre os maiores responsáveis pela criação de embaraços à efetivação dos provimentos judiciais se inscrevem os advogados. E só uma mal entendida proteção corporativa pode levar a querer proteger os maus advogados, que resistem injustificadamente às ordens judiciárias"

A medida coercitiva da prisão civil pelo descumprimento das decisões judiciais não foi inserida em nosso ordenamento ${ }^{142}$ e o parágrafo único do art. 14 do Código de Processo Civil hoje só contempla medidas punitivas cuja eficácia é questionável pela ausência de incidência imediata.

De lege lata ${ }^{143}$, o não atendimento de provimento judicial poderá caracterizar o crime de desobediência (art. 330 do Código Penal), cuja pena é de 15 dias a seis meses de detenção, além de multa. Porém, em razão do art. 61 da Lei no 9.099/95, o delito é considerado de menor potencial ofensivo, não se impondo ao infrator a prisão em flagrante ou o pagamento de fiança, quando assume o compromisso de comparecer ao Juizado Especial Criminal (art. 69, parágrafo único). Por conseguinte, será praticamente impossível a prisão do desobediente, ao qual ainda se confere a possibilidade de transacionar no processo penal com o Ministério Público.

Ainda assim, há forte orientação do Superior Tribunal de Justiça de que é ilegal a imputação do crime de desobediência a quem descumpre obrigação de fazer ou

\footnotetext{
${ }^{141}$ Id., ibid., p. 166.

${ }^{142}$ Se era intenção do legislador incorporar instituto estrangeiro, deveria ter em mente que a prisão pelo contempt of court, tanto no direito anglo-americano como no alemão, não é meio de punição do destinatário da ordem judicial descumprida, mas instrumento para coagi-lo a cumprir a obrigação. Invocando leading case, Roberto Goldschmidt assinala: "Imprisionment in such cases is not inflicted as a punishment, but intendend to be remedial by coercing the defendant to do what he had refused to do" (Las astreintes, las sanciones por contempt of court y otros..., p. 78).

${ }^{143}$ De lege ferenda, há o projeto de lei no $132 / 2004$ apresentado ao Senador Pedro Simon pela Associação dos Magistrados Brasileiros que prevê a prisão civil de natureza processual de até 60 dias nos casos em que a multa do $\S 1^{\circ}$ do art. 14 do CPC se revelar ineficaz ou persistir a renitência do destinatário da ordem judicial. Quanto à constitucionalidade do dispositivo, o Relator Demóstenes Torres defende que "é lícito concluir, por outra parte, que a previsão de novas hipóteses de prisão civil, no âmbito da legislação ordinária, não se acha vedada pelo ordenamento jurídico, desde que não seja motivada por dívida e seja respeitado o princípio do devido processo legal, a teor do disposto no mesmo art. $5^{\circ}$ da Constituição Federal, que, em seu inciso LIV, assegura que ninguém será privado da liberdade ou de seus bens sem o devido processo legal" (fonte: sítio do Instituto Brasileiro de Direito Processual).
} 
não fazer imposta no processo civil, em especial quando a própria ordem judicial tenha cominado alguma penalidade pelo descumprimento ${ }^{144}$.

De fato, esclarece Eduardo Talamini, "não é toda determinação de prestação de determinada conduta que, se descumprida, acarretará punição por desobediência" ${ }^{145}$. Os provimentos condenatórios e executivos, quando dotados de mecanismos subrogatórios da conduta do obrigado, não lhe endereçam uma ordem, assim como não se cogita em desobediência da parte que simplesmente descumpre um ônus processual, conforme acima visto.

Conclui o mencionado autor que "são apenas os atos judiciais de eficácia mandamental que veiculam propriamente uma ordem (mandado de segurança, tutela $e x$ art. 461, interdito proibitório, manutenção de posse, nunciação de obra nova, habeas data, habeas corpus etc). Ante estes, o não-acatamento é conduta que se pode enquadrar no crime de desobediência. Aqui não importa tanto a adesão teórica ao nome 'mandamental', mas o reconhecimento de que, entre os provimentos de 'repercussão física', uma fração deles se diferencia dos demais por conter comando direto à parte, a qual, se o descumpre, afronta a autoridade estatal"146.

Diante desse quadro, tornam-se inúteis outras considerações sobre o instituto do contempt of court.

\subsubsection{Astreintes.}

Instituto cuja criação é atribuída à jurisprudência francesa do Século XIX e severamente criticada pela doutrina de então ${ }^{147}$, a astreinte era definida pelos civilistas como uma pena pecuniária razoável, imposta ao devedor em atraso, suscetível de indefinida elevação e destinada a obter o cumprimento de obrigação ${ }^{148}$.

Duas circunstâncias provocaram o seu surgimento: a necessidade de encontrar um meio útil para o cumprimento de obrigações insuscetíveis de execução direta e o

\footnotetext{
${ }^{144}$ V. HC 16.940-DF, $5^{\text {a }}$ Turma, Rel. Jorge Scartezzini, DJU de 18.11.2002, p. 243; RHC 12.130-MG, $5^{\text {a }}$ Turma, Rel. Edson Vidigal, DJU de 18.3.2002, p. 276; HC 22.721, $5^{\text {a }}$ Turma, Rel. Felix Fischer, DJU de 30.6.2003, p. 271.

${ }_{145}$ Ainda sobre a prisão..., p. 289.

${ }^{146}$ Id., ibid., p. 290.

${ }^{147}$ As críticas ao instituto se baseavam no fato de que os tribunais violariam o princípio do nulla poena sine lege. Mas a evolução da doutrina francesa percebeu que a astreinte não tinha a função de uma sanção penal.

${ }_{148}$ É o que escreve Gr. Puricesco a partir da definição de Planiol (Des astreintes, p. 14).
} 
escopo de conferir ao credor não somente uma compensação pecuniária, mas a obtenção in natura da obrigação.

Mas a astreinte é acima de tudo um meio para compelir o destinatário da ordem judicial a cumpri-la e com a vantagem de ser utilizado nas obrigações de fazer infungíveis, nas quais se evidencia a impossibilidade prática do emprego dos mecanismos de sub-rogação.

Inspirado nesse instituto, o legislador brasileiro introduziu a "multa diária" nas ações de obrigação de fazer ou não fazer, inicialmente no art. 11 da Lei da Ação Civil Pública e, depois, nos artigos $213, \S 2^{\circ}$, do Estatuto da Criança e do Adolescente e 84, $\S$ $4^{\mathrm{o}}$, do Código de Defesa do Consumidor e, por fim no art. 461, $\S 4^{\circ}$, do Código de Processo Civil ${ }^{149}$.

A multa tem caráter coercitivo segundo o entendimento predominante, já que se destina a compelir o devedor à satisfação da obrigação. No entanto, torna-se difícil negar que em termos práticos e à semelhança das astreintes ${ }^{150}$, detém natureza de sanção a quem descumpre o provimento e de compensação ao credor, já que este é o beneficiário direto da multa e não o Estado ${ }^{151}$.

A legislação não estipula qualquer limite quantitativo ${ }^{152}$ ou temporal para a fixação da multa, de forma que a prudência do juiz no exame do caso concreto e à luz do princípio da proporcionalidade deve ser redobrada. A situação econômica dos litigantes é um fator relevante para que não haja enriquecimento sem causa do

\footnotetext{
${ }^{149}$ Convivem em nosso sistema diversas multas, mas a ora tratada não se relaciona diretamente com o ato atentatório à dignidade da Justiça, como é o caso das previstas nos artigos 18 e 601 do CPC.

150 "Les astreintes constituent une menace, une peine provisoire, une injonction, par lesquelles la justice, étant donné que tout droit acquis mérite une sanction, réussit à se faire obéir, même dans les circonstances où l'obstination du débiteur est capable de résister avec succès aux moyens édictés par la loi" (id., ib., p. 125).

${ }^{151}$ Oportunas as reflexões de Luiz Guilherme Marinoni à luz de nosso direito, bem como dos ordenamentos francês, alemão e português acerca do desvirtuamento dos objetivos dessa medida: "se a multa não surte os efeitos que dela se esperam, converte-se automaticamente em desvantagem patrimonial que recai sobre o réu inadimplente. Isto significa que a multa, de ameaça ou coerção, pode transformar-se em mera sanção pecuniária, que deve ser suportada pelo demandado, mas aí sem qualquer caráter de garantia de efetividade da ordem do juiz" (Tutela inibitória, p. 218). Na Alemanha a multa é paga ao Estado. Em França, ao adversário. Portugal tem solução intermediária: a multa é divida entre Estado e adversário. Nas demandas coletivas e no escopo de assegurar o caráter coercitivo da multa seria interessante destiná-la ao Fundo de Defesa dos Direitos Difusos e Individuais Homogêneos ou mesmo para o melhor aparelhamento e capacitação do Poder Judiciário.

${ }^{152}$ Porém, o Superior Tribunal de Justiça já decidiu que a multa "não se pode dar de forma desmesurada, sob pena de gerar o enriquecimento sem causa e ferir a própria lógica do razoável" (REsp. 793.491-RN, $4^{\mathrm{a}}$ Turma, Rel. César Asfor Rocha, j. 26.9.2006).
} 
beneficiário da multa nem uma onerosidade excessiva ou insignificância ao destinatário da ordem não cumprida.

Aplicada a multa em decisão antecipatória dos efeitos da tutela ou à guisa de liminar, a sua exigibilidade é imediata e perdurará até que sobrevenha a concessão de efeito suspensivo em eventual agravo de instrumento interposto pelo destinatário da ordem ou a cassação da decisão pela sentença de primeiro grau.

Do mesmo modo, tratando-se de cominação imposta pela sentença, a exigibilidade será imediata se não for interposto recurso de apelação recebido no efeito devolutivo.

O entendimento de que a multa só poderia ser cobrada com o trânsito em julgado da sentença que confirmar a sua imposição vai de encontro aos objetivos de propiciar efetividade à decisão judicial e de compelir o devedor a cumpri-la sem dilações injustas ${ }^{153}$.

Na ação civil pública, contudo, o $\S 2^{\circ}$ do art. 12 da Lei $n^{\circ} 7.347 / 85$ estabelece que a multa "só será exigível do réu após o trânsito em julgado da decisão favorável ao autor, mas será devida desde o dia em que se houver configurado o descumprimento". Igual disposição consta do Estatuto da Criança e do Adolescente e do Estatuto do Idoso.

Cassada a multa por decisão contra a qual não caiba mais nenhum recurso, obviamente a sua exigibilidade será extinta, pois não haveria sentido em impô-la a quem se reconheceu, com a autoridade da coisa julgada, a ausência de obrigação de fazer ou não fazer.

As disposições dos artigos 475-O e 811, do Código de Processo Civil, por seu turno, reparam as situações em que a multa foi efetivamente paga pelo destinatário da ordem judicial posteriormente revogada.

A responsabilidade do exeqüente é de natureza objetiva, de modo que na hipótese de cassação da multa, deverá restituí-la ao executado ${ }^{154}$.

\subsubsection{Outras medidas.}

\footnotetext{
${ }^{153}$ Ousamos discordar, portanto, do seguinte trecho de Luiz Guilherme Marinoni: "a finalidade coercitiva não se relaciona com a cobrança imediata da multa, mas apenas com a possibilidade da sua cobrança futura; essa possibilidade é suficiente para atemorizar o demandado e, assim, convencê-lo a adimplir" (Tutela inibitória, p. 226). Ora, a realidade demonstra que essa "cobrança futura" a depender do trânsito em julgado poderá levar anos, isto é, espaço de tempo suficiente para o desobediente contumaz esvaziar seu patrimônio e frustrar a técnica coercitiva.

${ }^{154}$ Nesse sentido: Paulo Henrique dos Santos Lucon (Eficácia das decisões e execução provisória, p. 279 e 367) e Sérgio Shimura (Tutela coletiva e sua efetividade, p. 113/114)
} 
O elenco exemplificativo do art. $84, \S 5^{\circ}$, do Código de Defesa do Consumidor cita entre as medidas necessárias para a obtenção do resultado prático equivalente ou para a tutela específica da obrigação a "busca e apreensão, remoção de coisas e pessoas, desfazimento de obra, impedimento de atividade nociva, além de requisição de força policial"'.

Mesclam-se nesse rol providências de sub-rogação, coerção e apoio ao provimento que podem ou não guardar estreita relação com o pedido. Por outro lado, também terão cabimento, sempre observado o princípio da proporcionalidade e a fundamentação da decisão, a título de medida subsidiária ou suplementar de outra providência anteriormente determinada.

A busca e apreensão é providência comum nas ações destinadas a coibir os delitos contra a propriedade industrial e se direciona a todas "as mercadorias, produtos, objetos, embalagens, etiquetas e outros que contenham a marca falsificada ou imitada" (art. 209, $\S 2^{\circ}$, da Lei $n^{\circ}$ 9.279/96). Igual medida poderá ser adotada, se o caso, nas ações coletivas que visem à retirada do mercado de produto nocivo à saúde do consumidor.

A requisição de força policial, por sua vez, nada tem de ilegal se evidenciada a intenção do destinatário da ordem judicial em resistir ao seu cumprimento com o emprego de violência ou anteriormente confrontado auxiliar do juízo no desempenho da diligência. Aliás, essa medida é também prevista para a execução em geral (art. 579 do CPC) e constitui manifestação do poder de coerção da jurisdição ${ }^{155}$.

Mais uma vez, a prudência e o bom senso, sem olvidar do controle da decisão pela via recursal, devem guiar a atuação do magistrado para que não incorra em abuso de poder ou arbitrariedade.

\section{Conclusões.}

4.1. Diante da repercussão social, política e econômica das demandas coletivas, exige-se do juiz papel mais ativo e criador na condução do processo.

\footnotetext{
155 “O poder de coerção se manifesta flagrantemente no processo de execução, quando se trata de compelir o vencido ao cumprimento da decisão. Mas também exerce-o o juiz nos processos de conhecimento e cautelares, como quando ordena a notificação de partes ou testemunhas, determina desentranhamento de documentos, comina ou aplica pena" (Moacir Amaral Santos. Primeiras linhas...,vol. 1, p. 71).
} 
4.2. Na escolha da medida mais adequada para a efetividade da tutela coletiva, em regra exteriorizada num fazer ou não fazer, o princípio da proporcionalidade e seus corolários limitarão a discricionariedade judicial.

4.3. Não há hierarquia entre as medidas de sub-rogação e de coerção, as quais serão empregadas de acordo com as peculiaridades do caso concreto.

4.5. Ressalvado o dever de fazer infungível, a conduta que se esperava do obrigado poderá ser obtida por meio de técnicas sub-rogatórias, cujos resultados serão mais úteis nos casos em que o destinatário da ordem judicial não tem patrimônio ou não é localizado.

\section{Bibliografia}

ALMEIDA, Gregório Assagra de. Direito processual coletivo: um novo ramo do direito processual. São Paulo: Saraiva, 2003.

ALMEIDA, João Batista de. A proteção jurídica do consumidor. São Paulo: Saraiva, 1993.

AMARAL SANTOS, Moacir. Primeiras linhas de direito processual civil, vol. 1. 12 $2^{\mathrm{a}}$ ed. São Paulo: Saraiva, 1985.

ANDOLINA, Italo Augusto. Il "giusto processo" nell'esperienza italiana e comunitaria. RePro 126/95, 2005.

ARAGÃO, Egas Dirceu Moniz de. Novas tendências da execução provisória. RePro 90/57, 1998.

ARAÚJO FILHO, Luiz Paulo da Silva. Ações coletivas: a tutela jurisdicional dos direitos individuais homogêneos. Rio de Janeiro: Forense, 2000.

ARRUDA ALVIM, José Manoel de. Notas sobre a disciplina da antecipação da tutela na Lei 10.444, de 7 de maio de 2002. RePro 108/105, 2002.

Manual de direito processual civil, vol. 2.

$11^{\mathrm{a}}$ ed. São Paulo: Revista dos Tribunais, 2007.

ASSIS, Araken de. Manual da execução. $11^{\mathrm{a}}$ ed. São Paulo: Revista dos Tribunais, 2007. 
BARBOSA MOREIRA, José Carlos. A proteção jurisdicional dos interesses coletivos ou difusos, "in” A tutela dos interesses difusos, p. 98/106.

Temas de direito processual, $1^{a}$ série.

São Paulo: Saraiva, 1977.

Temas de direito processual, $3^{a}$ série.

São Paulo: Saraiva, 1984.

Temas de direito processual, $4^{a}$ série.

São Paulo: Saraiva, 1989.

Temas de direito processual, $7^{a}$ série.

São Paulo: Saraiva, 2001.

Temas de direito processual, $8^{a}$ série.

São Paulo: Saraiva, 2002.

Notas sobre alguns aspectos do processo (civil e penal) nos países anglo-saxônicos. RePro 92/87, 1998.

Sentença executiva? RePro 114/147, 2004.

La significación social de las reformas

procesales. RePro 131/153, 2006.

A nova definição de sentença. RePro

136/268, 2006.

BEDAQUE, José Roberto dos Santos. Poderes instrutórios do juiz. $3^{\mathrm{a}}$ ed. São Paulo: Revista dos Tribunais, 2001.

Direito e processo: influência do

direito material sobre processo. São Paulo: Malheiros, 2003.

Efetividade do processo e técnica

processual. São Paulo: Malheiros, 2006.

BOBBIO, Norberto. Teoria do ordenamento jurídico. $10^{\mathrm{a}}$ ed. Brasília: Unb, 1982.

CABRAL, Antonio do Passo. O processo como superego social: um estudo sobre os fins sociais da jurisdição. RePro 115/345, 2004.

CAPPELLETTI, Mauro; GARTH, Bryant. Acess to justice - a world survey, vol. I, 1. 1. Milão: Giuffrè-Sijthoof, 1978.

CARNELUTTI, Francesco. Sistema de direito processual civil, vol. I. $1^{\text {a }}$ ed. São Paulo: Classic Book, 2000 (tradução Hiltomar Martins Oliveira). 
CHIOVENDA, Giuseppe. Instituições de direito processual civil, vol. 1. $1^{\text {a }}$ ed. Campinas: Bookseller, 1998 (tradução Paolo Capitanio).

CINTRA, Antonio Carlos de Araújo; GRINOVER, Ada Pellegrini; DINAMARCO, Cândido Rangel. Teoria Geral do Processo. São Paulo: Malheiros, $21^{\mathrm{a}}$ ed., 2005.

COUTURE, Eduardo Juan. Estudios de derecho procesal civil, Tomo 1. $3^{\mathrm{a}} \mathrm{ed}$. Buenos Aires: Depalma, 1998.

DENTI, Vittorio. Rapport général, “in” L'effectivité des décisions de justice (journées françaises), T. XXXVI. Paris : Economica, 1985, p. 29/46.

DINAMARCO, Cândido Rangel. A instrumentalidade do processo. $5^{\mathrm{a}}$ ed. São Paulo: Malheiros, 1996.

A reforma do Código de Processo Civil.

$5^{\text {a }}$ ed. São Paulo: Malheiros, 2001.

A reforma da reforma. $2^{\text {a }}$ ed. São Paulo:

Malheiros, 2002.

Instituições de direito processual civil,

vol. I. $4^{\text {a }}$ ed. São Paulo: Malheiros, 2004.

ELVINGER, Marc. Rapport luxembourgeois, “in" L'effectivité des décisions de justice (journées françaises), T. XXXVI. Paris: Economica, 1985, p. 199/211.

FARIA, José Eduardo de Campos. $O$ direito na economia globalizada. $2^{\mathrm{a}}$ ed. São Paulo: Malheiros, 2001.

FAZZALARI, Elio. Instituições de direito processual. Campinas: Bookseller, 2006 (tradução Elaine Nassif).

FERRAZ, Anna Candida da Cunha. Processos informais de mudança da Constituição: mutações constitucionais e mutações inconstitucionais. São Paulo: Max Limonad, 1986.

FERRAZ JÚNIOR, Tércio Sampaio. Introdução ao estudo do direito. $2^{\mathrm{a}}$ ed. São Paulo: Atlas, 1994.

FISS, Owen. Um novo processo civil. São Paulo: Revista dos Tribunais, 2004. Coordenação da tradução: Carlos Alberto de Salles. Tradução: Daniel Porto Godinho da Silva e Melina de Medeiros Rós.

FRIGNANI, Aldo. L'injunction nella common law e l'inibitoria nel diritto italiano. Milano: Giuffrè, 1974. 
FAGUNDES, M. Seabra. O controle dos atos administrativos pelo poder judiciário. $3^{\mathrm{a}}$ ed. Rio de Janeiro: Forense, 1957.

FIORILlO, Celso Antonio Pacheco; RODRIGUES, Marcelo Abelha. Manual de direito ambiental e legislação aplicável. 2a ed. São Paulo: Max Limonad, 1999.

FUX, Luiz. Tutela de segurança e tutela da evidência: fundamentos da tutela antecipada. São Paulo: Saraiva, 1996.

GIFIS, Steven H. Law dictionary. New Jersey: Barron's, 1996.

GOLDSCHMIDT, James. Direito processual civil, t. I e II. $1^{\text {a }}$ ed. Campinas: Bookseller, 2003.

GOLDSCHMIDT, Roberto. Las astreintes, las sanciones por contempt of court y otros medios para conseguir el cumplimiento de las obligaciones de hacer y non hacer, "in" Scritti giuridici in onore della CEDAM nel cinquantanario della sua fondazione. Padova: CEDAM, 1953, p. 61/88.

GRAU, Eros Roberto. A ordem econômica na Constituição de 1988. São Paulo: Saraiva, 1990.

GRINOVER, Ada Pellegrini. A tutela dos interesses difusos. São Paulo: Max Limonad, 1984.

O processo em evolução. Rio de Janeiro:

Forense Universitária, 2ª ed., 1998.

Da class action for damages à ação de classe brasileira: os requisitos de admissibilidade, “in” Ação Civil Pública - Lei 7.347/1985 15 anos. Coordenador: Édis Milaré. São Paulo: Revista dos Tribunais, 2000.

O processo: estudos e pareceres. São Paulo:

Perfil, 2005.

et alii. Código Brasileiro de Defesa do Consumidor comentado pelos autores do anteprojeto. $7^{\mathrm{a}}$ ed. Rio de Janeiro: Forense Universitária, 2001.

; WATANABE, Kazuo. Recepção e transmissão de institutos processuais civis. RePro 140/143, 2006.

GUERRA, Marcelo Lima. Execução indireta. São Paulo: Revista dos Tribunais, 1999.

GUIMARÃES, Mário. O juiz e a função jurisdicional. Rio de Janeiro: Forense, 1958. 
HERMAN, Shael; EZKOVICH, Alan. Rapport louisianais, “in” L'effectivité des décisions de justice (journées françaises), T. XXXVI. Paris: Economica, 1985, p. $171 / 197$.

HOFFMAN, Paulo. Razoável duração do processo. São Paulo: Quartier Latin, 2006.

KECKLER, Charles. Ações coletivas em relações de consumo, "in” Seminário internacional de responsabilidade civil: OAB/RJ. Rio de Janeiro: Justiça \& Cidadania, 2004, p. 71/102.

KELSEN, Hans. Teoria pura do direito. São Paulo: Martins Fontes, 1999.

LACERDA, Galeno. Comentários ao Código de Processo Civil, vol. VIII, t. I. $10^{\mathrm{a}}$ ed. Rio de Janeiro: Forense, 2007.

LASPRO, Oreste Nestor de Souza. A responsabilidade civil do juiz. São Paulo: Revista dos Tribunais, 2000.

LEAL, Márcio Flávio Mafra. Ações coletivas: história, teoria e prática. Porto Alegre: Sérgio Antonio Fabris, 1998.

LEVAL, Georges de. Rapport belge, "in" L'effectivité des decisions de justice (journées françaises), T. XXXVI. Paris: Economica, 1985, p. 49/69.

LIEBMAN, Enrico Tullio. Problemi del processo civile. Nápoles: Morano, 1962.

Eficácia e autoridade da sentença e outros escritos sobre a coisa julgada. Rio de Janeiro: Forense, 3ª ed., 1984. Tradução: Alfredo Buzaid e Benvindo Aires. Notas e tradução: Ada Pellegrini Grinover.

Manual de direito processual civil, vol. I. $3^{\mathrm{a}}$ ed.

São Paulo: Malheiros, 2005. Tradução: Cândido Rangel Dinamarco.

LOPES, João Batista. Efetividade da tutela jurisdicional à luz da constitucionalização do processo civil. RePro 116/29, 2004.

LUCON, Paulo Henrique dos Santos. Eficácia das decisões e execução provisória. São Paulo: Revista dos Tribunais, 2000.

Garantia do tratamento paritário das partes, “in” Garantias constitucionais do processo civil. $1^{\mathrm{a}}$ ed. São Paulo: Revista dos Tribunais, 1999. Coordenador: José Rogério Cruz e Tucci.

MANCUSO, Rodolfo de Camargo. Interesses difusos. São Paulo: Revista dos Tribunais, 1988 . 
Tribunais, 1996.

MARENGO, Roberto. Note in tema di discrezionalità del giudice civile. RePro 86/158, 1997.

MARINONI, Luiz Guilherme. Tutela especifica: (arts. 461, CPC e 84, CDC). São Paulo: Revista dos Tribunais, 2000. Tutela inibitória (individual e coletiva). $4^{\mathrm{a}}$ ed.

São Paulo: Revista dos Tribunais, 2006.

MAZZILLI, Hugo Nigro. A defesa dos interesses difusos em juizo. $15^{\mathrm{a}}$ ed. São Paulo: Saraiva, 2002.

MELLO. Celso Antônio Bandeira de. Discricionariedade e controle jurisdicional. São Paulo: Malheiros, 1992.

MENDES, Aluisio Gonçalves de Castro. Ações coletivas no direito comparado e nacional. São Paulo: Revista dos Tribunais, 2002.

MILLER, C.J. Contempt of court. Oxford: Clarendon Press, 1989.

MORAES, Alexandre de. Direito constitucional. 9a ed. São Paulo: Atlas, 2001.

NEIVA, Deirdre de Aquino. A tutela antecipada e os limites da discricionariedade do juiz, "in” Temas de direito: homenagem ao Ministro Humberto Gomes de Barros. Rio de Janeiro: Forense, 2000, p. 211/216.

NERY JÚNIOR, Nelson. Princípios do processo civil na Constituição Federal. $7^{\mathrm{a}}$ ed. São Paulo: Revista dos Tribunais, 2002.

; NERY, Rosa Maria Andrade. Código de Processo Civil Comentado. $4^{\text {a }}$ ed. São Paulo: Revista dos Tribunais, 1999.

NEVES, Celso. Coisa julgada civil. São Paulo: Revista dos Tribunais, 1971. Estrutura fundamental do processo civil. Rio de Janeiro:

Forense, 1995.

PISANI, Andrea Proto. I provvedimenti anticipatori di condanna, "in" La riforma di processo civile. Verona: CEDAM, 1992, p. 115/139.

PONTES DE MIRANDA, Francisco Cavalcanti. Tratado das ações, t. I e IV. $2^{\mathrm{a}}$ ed. Campinas: Bookseller, 1999.

PURICESCO, Gr. Des astreintes. Paris: Dalloz, 1914.

REALE, Miguel. Filosofia do direito. 20a ed. São Paulo: Saraiva, 2002. 
SÁ, Fernando. Astreinte e contempt of court: eficácia e efetividade (estudo de um caso). RePro 115/205, 2004.

SALLES, Carlos Alberto de. Execução judicial em matéria ambiental. São Paulo: Revista dos Tribunais, 1998.

Políticas públicas e a legitimidade para defesa de interesses difusos e coletivos. RePro 121/38, 2005.

Processo civil de interesse público: uma nova perspectiva metodológica, "in” Direito processual público: a Fazenda Pública em juízo. São Paulo: Malheiros, 2000. Coordenação: Carlos Ari Sundfeld e Cássio Scarpinella Bueno.

SHIMURA, Sérgio. Tutela coletiva e sua efetividade. São Paulo: Método, 2006.

SILVA, José Afonso da. Curso de Direito Constitucional positivo. $7^{\mathrm{a}}$ ed. São Paulo: Revista dos Tribunais, 1991.

SILVA, Ovídio A. Baptista. Teoria geral do processo. $5^{\mathrm{a}}$ ed. São Paulo: Revista dos Tribunais, 2001.

SOARES, Guido Fernando Silva. Common law: introdução ao direito dos EUA. $2^{\text {a }}$ ed. São Paulo: Revista dos Tribunais, 2000.

STOCO, Rui. Abuso do direito e má-fé processual. São Paulo: Revista dos Tribunais, 2002.

TALAMINI, Eduardo. Tutela relativa aos deveres de fazer e de não fazer. São Paulo: Revista dos Tribunais, 2001.

Ainda sobre a prisão como "execução indireta": a criminalização da desobediência a ordens judiciais, "in” Processo de execução. São Paulo: Revista dos Tribunais, 2001. Coordenação: Sérgio Shimura e Teresa Arruda Alvim Wambier, p. 279/313.

TARZIA, Giuseppe. La tutela inibtioria contro le clausole vessatorie. RePro 114/131, 2004.

Problemas atuais da execução forçada. RePro 90/68, 1998.

Les mesures provisoires en procédure civile (organiz).

Milano: Giuffrè, 1985.

TEIXEIRA, Sálvio de Figueiredo. A reforma do CPC (coord.). São Paulo: Saraiva, 1996. 
88/157, 1997.

THEODORO JÚNIOR, Humberto. O cumprimento das medidas cautelares e antecipatórias. RePro 139/7, 2006.

TUCCI, José Rogério Cruz e. Código do consumidor e processo civil: aspectos polêmicos. RT 671/34.

VIGORITI, Vicenzo. Interessi colettivi e processo: la legittimazione ad agire. Milano: Giuffrè, 1979.

VILLONE, Massimo. La colocazione istituzionale dell'interesse difuso, "in" La tutela degli interessi diffusi nel Diritto Comparato. Milano: Giuffrè, 1979.

WAMBIER, Teresa Arruda Alvim; SHIMURA, Sérgio. Processo de execução (coord.). São Paulo: Revista dos Tribunais, 2001.

WATANABE, Kazuo. Tutela jurisdicional dos interesses difusos: a legitimação para agir, "in” A tutela jurisdicional dos interesses difusos. São Paulo: Max Limonad, 1984, p. 85/97.

Novas atribuições do Judiciário: necessidade de sua percepção e reformulação de mentalidade. Revista da Escola Paulista da Magistratura, set/dez 1996, p. 149/151.

Tutela antecipatória e tutela específica das obrigações de fazer e não fazer, "in” Reforma do Código de Processo Civil. São Paulo: Saraiva, 1996 (coord. Sálvio de Figueiredo Teixeira), p. 19/51.

Código brasileiro de defesa do consumidor comentado pelos autores do anteprojeto. $7^{\mathrm{a}}$ ed. Rio de Janeiro: Forense Universitária, 2001.

Demandas coletivas e os problemas emergentes de práxis forense, "in” As garantias do cidadão na justiça. São Paulo: Saraiva, 1993 (coord. Sálvio de Figueiredo Teixeira), p. 185/196.

Relação entre demanda coletiva e demandas individuais. RePro 139/28, 2006.

YARSHELL, Flávio Luiz. Tutela jurisdicional específica nas obrigações de declaração de vontade. São Paulo: Malheiros, 1993.

ZAVASCKI, Teori Albino. Defesa de direitos coletivos e defesa coletiva de direitos. RF 329/147. Antecipação da tutela. $5^{\mathrm{a}}$ ed. São Paulo: Saraiva, 2007. 
